$$
\begin{aligned}
& \text { QRIGHT TART } \\
& \text { ALASSIFICATION } \\
& \text { OFTHE } \\
& \text { P. W. \& B. R. R. }
\end{aligned}
$$








\section{FREIGHT TARIFF}

and

\section{CLASSIFICATION \\ OF THE}

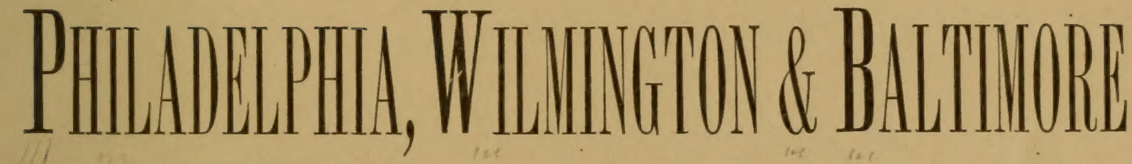

\section{$=$ RAILROAD}

TO TAKE EFFECT OCTOBER $25 \mathrm{th}, 1877$.

THIS TARIF SUPERSEDES ALI FORMER ISSUES, AND ALL SPECIAL RATES CONFLICTING WITH IT ARE ABROGATED.

H. F. KENNEY,

SUPERINTENDENT.
I. N. MILLS,

General Agent Delaware Division.

\section{JOHN S. WILSON, \\ General Freight Agent.}

PHILADELPHIA :

The Chandler Printing House, 306-8 Chestnut street.

1880 . 


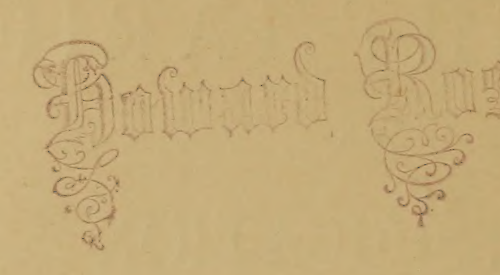

\section{IMPORTANT INSTRUCTIONS TO AGENTS.}

This Tariff and Classification is intended to apply to Freight received, loaded, discharged, and delivered at the regular Freight Stations of the Company.

When Special Rates are wanted, application must be made to this office.

\section{JOHN S. WILSON,}

General Freight Agent.

\section{LIBRARY}




\section{TARIFF OF RATES,}

SHOWING THE RATE PER 100 LBS. IN CENTS FOR ANY DISTANCE, IN FOUR CLASSES, FROM ONE MILE TO TWO HUNDRED AND FIFTEEN MILES, INCLUSIVE.

\begin{tabular}{|c|c|c|c|c|c|c|c|c|c|}
\hline MILES. & $\begin{array}{l}\text { First } \\
\text { Class. }\end{array}$ & $\begin{array}{l}\text { Second } \\
\text { Class. }\end{array}$ & $\begin{array}{l}\text { Third } \\
\text { Class. }\end{array}$ & $\begin{array}{l}\text { Fourth } \\
\text { Class. }\end{array}$ & MILES, & $\begin{array}{l}\text { First } \\
\text { Class. }\end{array}$ & $\begin{array}{l}\text { Second } \\
\text { Class. }\end{array}$ & $\begin{array}{l}\text { Third } \\
\text { Class. }\end{array}$ & $\begin{array}{c}\text { Fourth } \\
\text { Class. }\end{array}$ \\
\hline 1 & 10 & 8 & 6 & 5 & 32 & 14 & 12 & 10 & 7 \\
\hline 2 & 10 & 8 & 6 & 5 & 33 & 14 & 12 & 10 & 7 \\
\hline 3 & 10 & 8 & 6 & 5 & 34 & 14 & 12 & 10. & 7 \\
\hline 4 & 10 & 8 & 6 & 5 & 35 & 14 & 12 & 10 & 7 \\
\hline 5 & 10 & 8 & 6 & 5 & 36 & 14 & 12 & 10 & 7 \\
\hline 6 & 10 & 8 & 6 & 5 & 37 & 14 & 12 & 10 & 7 \\
\hline 7 & 10 & 8 & 6 & 5 & 38 & 14 & 12 & 10 & 7 \\
\hline 8 & 10 & 8 & 6 & 5 & 39 & 16 & 13 & 11 & 8 \\
\hline 9 & 10 & 8 & 6 & 5 & 40 & 16 & 13 & 11 & 8 \\
\hline 10 & 10 & 8 & 6 & 5 & 41 & 16 & 13 & 11 & 8 \\
\hline 11 & 10 & 8 & 6 & 5 & 42 & 16 & 13 & 11 & 8 \\
\hline 12 & 12 & 10 & 8 & 6 & 43 & 16 & 13 & 11 & 8 \\
\hline 13 & 12 & 10 & 8 & 6 & 44 & 16 & 13 & 11 & 8 \\
\hline 14 & 12 & 10 & 8 & 6 & 45 & 16 & 13 & 11 & 8 \\
\hline 15 & 12 & 10 & 8 & 6 & 46 & 16 & 13 & 11 & 8 \\
\hline 16 & 12 & 10 & 8 & 6 & 47 & 16 & 13 & 11 & 8 \\
\hline 17 & 12 & 10 & 8 & 6 & 48 & 16 & 13 & 11 & 8 \\
\hline 18 & 12 & 10 & 8 & 6 & 49 & 16 & 13 & 11 & 8 \\
\hline 19 & 12 & 10 & 8 & 7 & 50 & 18 & 15 & 12 & 9 \\
\hline 20 & 12 & 10 & 8 & 7 & 51 & 18 & 15 & 12 & 9 \\
\hline 21 & 12 & 10 & 8 & 7 & 52 & 18 & 15 & 12 & 9 \\
\hline 22 & 12 & 10 & 8 & 7 & 53 & 18 & 15 & 12 & 9 \\
\hline 23 & 12 & 10 & 8 & 7 & 54 & 18 & 15 & 12 & 9 \\
\hline 24 & 12 & 10 & 8 & 7 & 55 & 18 & 15 & 12 & 9 \\
\hline 25 & 12 & 10 & 8 & 7 & 56 & 18 & 15 & 12 & 9 \\
\hline 26 & 12 & 10 & 8 & 7 & 57 & 18 & 15 & 12 & 9 \\
\hline 27 & 12 & 10 & 8 & 7 & 58 & 18 & 15 & 12 & 9 \\
\hline 28 & 12 & 10 & 8 & 7 & 59 & 18 & 15 & 12 & 9 \\
\hline 29 & 14 & 12 & 10 & 7 & 60 & 20 & 17 & 13 & 10 \\
\hline 30 & 14 & 12 & 10 & 7 & 61 & 20 & 17 & 13 & 10 \\
\hline 31 & 14 & 12 & 10 & 7 & 62 & 20 & 17 & 13 & 10 \\
\hline
\end{tabular}




\begin{tabular}{|c|c|c|c|c|c|c|c|c|c|}
\hline MILES. & $\begin{array}{l}\text { First } \\
\text { Class. }\end{array}$ & $\begin{array}{l}\text { Second } \\
\text { Class. }\end{array}$ & $\begin{array}{l}\text { Third } \\
\text { Class. }\end{array}$ & $\begin{array}{l}\text { Fourth } \\
\text { Class. }\end{array}$ & MILES. & $\begin{array}{l}\text { First } \\
\text { Class. }\end{array}$ & $\begin{array}{l}\text { Second } \\
\text { Class. }\end{array}$ & $\begin{array}{l}\text { Third } \\
\text { Class. }\end{array}$ & $\begin{array}{c}\text { Fourth } \\
\text { Class. }\end{array}$ \\
\hline 63 & 20 & 17 & 13 & 10 & 102 & 27 & 22 & 15 & 12 \\
\hline 64 & 20 & 17 & 13 & 10 & 103 & 27 & 22 & 15 & 12 \\
\hline 65 & 20 & 17 & 13 & 10 & 104 & 27 & 22 & 15 & 12 \\
\hline 66 & 20 & 17 & 13 & 10 & 105 & 27 & 22 & 15 & 12 \\
\hline 67 & 20 & 17 & 13 & 10 & 106 & 27 & 22 & 15 & 12 \\
\hline 68 & 20 & 17 & 13 & 10 & $10 \%$ & 27 & 22 & 15 & 12 \\
\hline 69 & 20 & 17 & 13 & 10 & 108 & 27 & 22 & 15 & 12 \\
\hline 70 & 20 & 17 & 13 & 10 & 109 & 27 & 22 & 15 & 12 \\
\hline 71 & 22 & 19 & 14 & 11 & 110 & 30 & 22 & 17 & 14 \\
\hline 72 & 22 & 19 & 14 & 11 & 111 & 30 & 22 & 17 & 14 \\
\hline 73 & 22 & 19 & 14 & 11 & 112 & 30 & 22 & -17 & 14 \\
\hline 74 & 22 & 19 & 14 & 11 & 113 & 30 & 22 & 17 & 14 \\
\hline 95 & 22 & 19 & 14 & 11 & 114 & 30 & 22 & 17 & 14 \\
\hline 76 & 22 & 19 & 14 & 11 & 115 & 30 & $2 \cdot 2$ & 17 & 14 \\
\hline 77 & 22 & 19 & 14 & 11 & 116 & 30 & 22 & 17 & 14 \\
\hline 78 & 22 & 19 & 14 & 11 & 117 & 30 & 22 & 17 & 14 \\
\hline 79 & 22 & 19 & 14 & 11 & 118 & 30 & 22 & 17 & 14 \\
\hline 80 & 22 & 19 & 14 & 11 & 119 & 30 & 22 & 17 & 14 \\
\hline 81 & 22 & 19 & 14 & 11 & 120 & 32 & 23 & 18 & 15 \\
\hline 82 & 22 & 19 & 14 & 11 & 121 & 32 & 23 & 18 & 15 \\
\hline 83 & 25 & 20 & 15 & 12 & 122 & 32 & 23 & 18 & 15 \\
\hline 84 & 25 & 20 & 15 & 12 & 123 & 32 & 23 & 18 & 15 \\
\hline 85 & 25 & 20 & 15 & 12 & 124 & 32 & 23 & 18 & 15 \\
\hline 86 & 25 & 20 & 15 & 12 & 125 & 32 & 23 & 18 & 15 \\
\hline 87 & 25 & 20 & 15 & 12 & 126 & 32 & 23 & 18 & 15 \\
\hline 88 & 25 & 20 & 15 & 12 & 127 & 32 & 23 & 18 & 15 \\
\hline 89 & 25 & 20 & 15 & 12 & 128 & 32 & 23 & 18 & 15 \\
\hline 90 & 25 & 20 & 15 & 12 & 129 & 32 & 23 & 18 & 15 \\
\hline 91 & 25 & 20 & 15 & 12 & 130 & 32 & 23 & 18 & 15 \\
\hline 92 & 25 & 20 & 15 & 12 & 131 & 32 . & 23 & 18 & 15 \\
\hline 93 & 25 & 20 & 15 & 12 & 132 & 32 & 23 & 18 & 15 \\
\hline 94 & 25 & 20 & 15 & 12 & 133 & 32 & 23 & 18 & 15 \\
\hline 95 & 25 & 20 & 15 & 12 & 134 & 35 & 28 & 20 & 16 \\
\hline 96 & 25 & 20 & 15 & 12 & 135 & 35 & 28 & 20 & 16 \\
\hline 97 & 25 & 20 & $i 5$ & 12 & 136 & 35 & 28 & 20 & 16 \\
\hline 98 & 27 & 22 & 15 & 12 & 137 & 35 & 28 & 20 & 16 \\
\hline 99 & 27 & 22 & 15 & 12 & 138 & 35 & 28 & 20 & 16 \\
\hline 100 & 27 & 22 & 15 & 12 & 139 & 35 & 28 & 20 & 16 \\
\hline 101 & 27 & 22 & 15 & 12 & 140 & 35 & 28 & 20 & 16 \\
\hline
\end{tabular}




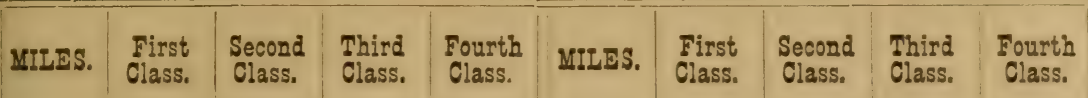

\begin{tabular}{|c|c|c|c|c|c|c|c|c|c|}
\hline 141 & $3 \bar{\jmath}$ & 28 & 20 & 16 & 179 & 42 & 34 & 25 & 20 \\
\hline 142 & 35 & 28 & 20 & 16 & 180 & 45 & 36 & 26 & 21 \\
\hline 143 & 37 & 30 & 22 & 17 & 181 & 45 & 36 & 26 & 21 \\
\hline 114 & 37 & 30 & 22 & 17 & 152 & 45 & 36 & 26 & 21 \\
\hline 145 & 37 & 30 & 22 & 17 & 183 & 45 & 36 & 26 & 21 \\
\hline 146 & 37 & 30 & 22 & 17 & 181 & 45 & 36 & 26 & 21 \\
\hline 147 & 37 & 30 & 22 & 17 & 185 & 45 & 36 & 26 & 21 \\
\hline 148 & 37 & 30 & 22 & 17 & 186 & 45 & 36 & 26 & 21 \\
\hline 119 & 37 & 30 & 22 & 17 & 187 & 45 & 36 & 26 & 21 \\
\hline 150 & 37 & 30 & 22 & 17 & 188 & 45 & 36 & 26 & 21 \\
\hline 151 & 37 & 30 & 22 & 17 & 189 & 45 & 36 & 26 & 21 \\
\hline 152 & 40 & 32 & 23 & 18 & 190 & 47 & 36 & 27 & 22 \\
\hline 153 & 40 & 32 & 23 & 18 & 191 & 47 & 36 & 27 & 22 \\
\hline 154 & 40 & 32 & 23 & 18 & 192 & 47 & 36 & 27 & 22 \\
\hline 15.5 & 40 & 32 & 23 & 18 & 193 & 47 & 36 & 27 & 22 \\
\hline 156 & 40 & 32 & 23 & 18 & 191 & 47 & 36 & 27 & 22 \\
\hline 157 & 40 & 32 & 23 & 18 & 195 & 47 & 36 & 27 & 22 \\
\hline 158 & 40 & 32 & 23 & 18 & 196 & 47 & 36 & 27 & 22 \\
\hline 159 & 40 & 32 & 23 & 18 & 197 & 47 & 36 & 27 & 22 \\
\hline 160 & 40 & 32 & 23 & 18 & 198 & 47 & .36 & 27 & 22 \\
\hline 161 & 40 & 32 & 23 & 18 & 199 & 47 & 36 & 27 & 22 \\
\hline 162 & 40 & 32 & 23 & 18 & 200 & 47 & 36 & 27 & 22 \\
\hline 163 & 40 & 32 & 23 & . 18 & 201 & 47 & 36 & 27 & 22 \\
\hline 161 & 42 & 34 & 25 & 20 & 202 & 47 & 36 & 27 & 22 \\
\hline 165 & 42 & 34 & 25 & 20 & 203 & 50 & 36 & 27 & 22 \\
\hline 166 & 42 & 34 & 25 & 20 & 201 & 50 & 36 & 27 & 22 \\
\hline 167 & 42 & 34 & 25 & 20 & 205 & 50 & 36 & 27 & 22 \\
\hline 168 & 42 & 34 & 25 & 20 & 206 & 50 & 36 & 27 & 22 \\
\hline 169 & 42 & 34 & 25 & 20 & 207 & 50 & 36 & 27 & 22 \\
\hline 170 & 42 & 34 & 25 & 20 & $\mathbf{2 0 8}$ & 50 & 36 & 27 & 22 \\
\hline 171 & 42 & 34 & 25 & 20 & 209 & 50 & 36 & 27 & 22 \\
\hline 172 & 42 & 34 & 25 & 20 & 210 & 50 & 36 & 27 & 22 \\
\hline 173 & 42 & 34 & 25 & 20 & 211 & 50 & 36 & 27 & 22 \\
\hline 174 & 42 & 34 & 25 & 20 & 212 & 52 & 37 & 28 & $2: 3$ \\
\hline 175 & 42 & 34 & 25 & 20 & 213 & 52 & 37 & 28 & 23 \\
\hline 176 & 42 & 34 & 25 & 20 & 211 & 52 & 37 & 28 & 23 \\
\hline 177 & 42 & 34 & 25 & 20 & 215 & 52 & 37 & 28 & 23 \\
\hline 178 & 42 & 34 & 25 & 20 & & & & & \\
\hline
\end{tabular}





\section{(1) laşsification of}

\section{EXPLANATION OF CLASSIFICATION.}

The number of the class is given opposite each article:-I stands for First Class; 2 for Second Class; 3 for Third Class; 4 for Fourth Class; I I I I for once and $a$ half First Class; D I for double First Class.

Articles noted O. R. will only be taken at OWNER'S RISK, and such articles must be so considered by the shipper, so receipted for, and so manifested.

When an invoice or single shipment covers a variety of articles and their total weight is less than 200 pounds, they will all be considered First Class, and so manifested.

Articles not enumerated will be classed with analogous articles.

\section{A}

ACIDS, Acetic, in wood, . . . I ALKANET ROOT, . . . . . I

" in carboys, full car loads, . I " " less than full car loads, . . , . . . . . D. I

AGRICULTURAL IMPLEMENTS, not otherwise specified, in full car loads, (see estimate of weights), . I AGRICULTURAL IMPLEMENTS, less than car loads, (see estimated weights),

AGRICULTURAL IMPLEMENTS, knocked down or boxed, . . . 2 AGRICULTURAL products, not otherwise specified, . . . . . 2 ALABASTER, . . . . . . I ALCOHOL, in barrels or casks, . 2 " in cans, . . . . . I ALE, in wood, . . . . . . . 3 " in glass or stoneware, packed O. R.,

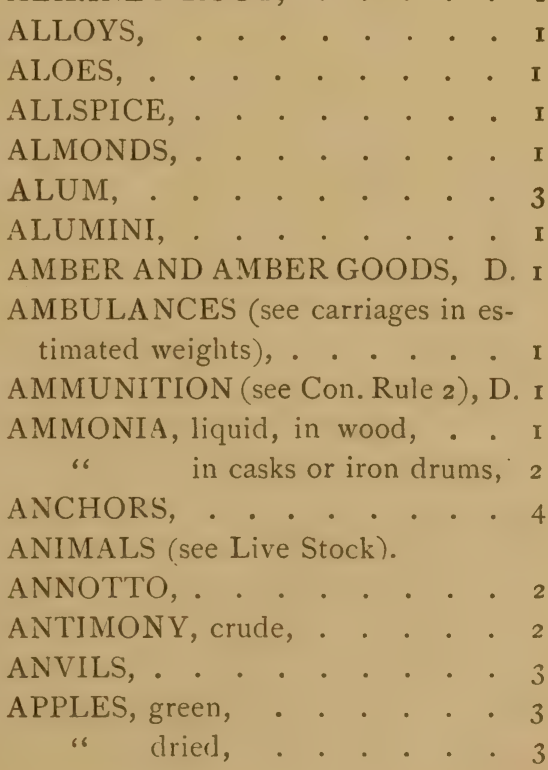


APPLE BUTTER OR SAUCE, .

“ PARERS,

ARROW ROOT,

ARSENIC, .

ASHES, Pot or Pearl, . • . . 3

"Wood, over 10,000 lbs. by

special rates; less than 10,000

lbs.,. .

ASPARAGUS, green, prepaid, O.R., I
ASPHALTUM, .

AWLS, Shoemakers', in boxes, . . I

AXES, in boxes, . . . . 3

AXE HANDLES, in boxes or bdls., 3

"6 in rough, . . 3

AXLES, Car, in rough or finished, 4

" Iron Wagon, . . . . 2

AXLE GREASE, • . . . . . 4

\section{B}

BACON, loose, . • • • • • 2

" in hhds. or casks, . . . 4

BACKGAMMON BOARDS, in cases, I

BAGS, empty (see empties), . . . I

BAGATELLE BOARDS, set up, not boxed or packed, . . . O. R., D. I

BAGATELI.E BOARDS, knocked down or packed, . . . . . . I

BAGGING, in bales, . . . . 2

BAKING POWDERS, • . . . 2

BALANCE WHEELS, $7 \mathrm{ft}$. in ciam-

eter and upwards, . . . . . I

BALED ROPE, . • . . . . 4

BALLOONS, packed, . . . . D. I

BANDBOXES, . . . . . D. I

BAREGES, in cases, . . . . . I

BARILLA, • • • • . • . 3

BARK, loose, . . . . . . 3

" ground, in hhds.,. . . . 4

" " Peruvian, . . . . . I

"Quercitron, . . . . . 3

" Slippery Elm, in bxs. or bls., I

" Mills or Cob Mills, . . . 2

BARLEY,

BARRELS, empty, Ale, Beef or

Pork, (see estimated weights), . 2

BARRELS, empty halves, Ale, Beef

or Pork, (see estimated weights), 2

BARRELS, empty Flour, less than car loads, (see estimated weights), 2

BARREIS, empty Flour, in full car loads, (see estimated weights), . 3
BARYTES, • . . . . . . . 4

BASKETS, • . • . . . . D. I

BATH BRICKS, . . . . . 3

"Tubs, in nests, . . . . I

" " single, • • . . D. I

BATTING, in bales, . . . D. I

BEADS, in boxes or barrels, . . I

BEANS, dry, • • • • • • 3

" green, prepared, O.R., I

BED CORDS, in bundles, . . . 2

BEDSTEADS, Iron, . . . . . 2

"Wooden, • . . I

" Stuff, finished, . . I

" " 6 in rough, . . 2

" Slate, in bundles, . I

BED SPRINGS, . . . . D. I

BEDS AND MATTRESSES, . I). I

BEEF, Fresh, prepaid, - O. R., I

" Salted, . . . . . . 4

"Tongues, pickled or dried, . 2

BEE HIVES, • . . . . . D. I

BEER, in wood, . . . . . 3

" in glass or stoneware, packed,

O. R., • . • . • . . 2

BEESWAX, . . . . . . . . I

BEETS, early, in bunches, prepaid in

crates, boxes, \&c., . . . O. R., 2

BEETS, late, in barrels, . . . 3

BELLOWS, . . . . . . . I

BELLS, . . . . . . . . . I

BELTING, • . • . . • . 2 
BENZINE (see Rule No. 3 of Conditions),

O. R., I

BENZOLE,

O. R., I

BERRIES, dried, not otherwise specified,

BERRIES, green, not otherwise specified, prepaid, . . . O. R., I BILLIARD TABLES, knocked down and boxed, . . . . O. R., I BILLIARD TABLES, set up, not packed or boxed, . . O. R., D. I BIRD CAGES, not received unless boxed, . D. I BITTERS, in glass, packed, O. R., I " in wood, . . . . . I BITUMINOUS COAL, . . • . 4 BLACK LEAD, in barrels, . • . 3 BLACKING, Shoe or Stove, . . 4 BLANKETS, in bales, . . . . I " in boxes,

BLEACHING POWDERS, . . . 4 BLINDS or SHUTTERS, . . . I BLOOMS, in car loads, . . . . 4 BLOWING ENGINES, . . . . I BLUE VITRIOL, . . . . . . 3 BOATS, . . . . . . D. I BOILER FELTING, . . . . . 2 BOILERS, Steam, 28 feet long and over, BOILERS, Steam, under 28 feet long, BOILERS, Sectional, in parts, . . 2 " " FLUES, • • • • • 2 BOLSTERS, Feather or Hair, . D. I BOLTS and NUTS, Iron, . . . 3 BONES, in bulk, . . . . . 4 BONE BLACK, “ DUST, BONNETS, . BOOKS, only received in boxes,
BOOK MUSLIN, . . . . . I BOOTS and SHOES, . . . . . I BOOT CRIMPS, . . . . . . I BOTTLED LIQUIDS, not otherwise specified, packed, . . O. R., I BORACIC ACID, . . . . . I BORAX, . . . . . . 3 BOWS and FELLOES, in bundles, 2 " " " in rough, . 3 BOTTLES, empty, packed in crates, casks or barrels, . . . O. R., I BOXES, empty, . . . I I I 2 I $\because \quad$ " in car loads (see es-

timated weights), . . . . . 3 BOXWOOD, . . . . . . . 2 BRANDY, in wood, Foreign, . . I " " Domestic, . . I " in glass, packed, O. R., I I $1 / 2$ I BRASS, Manyfactured, . . . I " Rough, . . . . . . 2 " and STRING MUSICAL INSTRUMENTS, . . . . D. I BREAD, .

BREWERS' GRAINS, SPENTS or MALTS, BRICKS, Common, in car loads, . 4 "Bath, . . . . . 3 " Fire, in car loads, . . 4 " Stove, in bundles or loose, I " " in boxes or casks, . 3 BRICK PRESSES, knocked down, 3 " " set up, . . . I BRIMSTONE, in hhds, or bbls., . 4 BRISTLES, . . . . . . . . I BRITANNIA WARE, . . . . I BROKEN CASTINGS, . . . . 4 BROOM CORN, pressed in bales, . 2 BROOMS, (see estimated weights), I BROOM HANDLES, finished in bundles, . . . . . . . . 2 BROOM HANDLES, in rough or loose, . . . . . . . . 3 BRUSHES, in hoxes, . . . . I 
BUCKETS, Well, " other than Well, I I $1 / 2$ I BUCKWHEAT,

" Flour in barrels, . 4 BUFFALO ROBES, not taken unless securely packed, . . I I $/ 2$ I BUILDING STONE, in rough, . 4 " " Wrought, . 3 BUNGS or PLUGS, in barrels, . 2 BUOYS, Iron, . . . . $\mathrm{I} 1 / 2 \mathrm{I}$
BUOYS, Wood,

BUREAUS, .

BURIAL CASES, ${ }^{\circ}$

BURNING FLUID, BURLAPS,

BURR BLOCKS,

BUTTER, Fresh, prepaid, O. R., I " Salted and packed, . . 2 BUTTONS, . . . . . . . I
CABBAGES, prepaid, . O. R., I " in car loads, prepaid,

O. R.,

CABINET ORGANS, only received well packed,

CABINET WA RE, knocked down, 2 " " set up, boxed,

or matted,

CALORIC ENGINES, . . . . I

CAISSONS and LIMBERS, . . . I

CALICO, in cases, . . . . . I

CALF SKINS, dressed, . . . . I

" " green,. . . . . 3

CALVES, (see estimated weights of Live Stock),

CALVES, in car loads, (see estimated weights of Live Stock), . . . 4 CAMPHENE, (see Rule No. 3), O. R., I CAMPHOR GUM, . . . . . I CAMP KETTLES, • • . • D. I CANDLES, Common, . . . . 3 "Sperm or Adamantine, I CANE, Sugar or Sorghum, . . . 2 " Rattan, in bundles, . . . I CANES, Walking, in cases, . . . I CANNED FRUITS, VEGETABLES or MEATS, CANNED FRUITS, VEGETABLES or MEATS, in car loads, . 4 CANNON and CANNON BALLS, 4
CANS, empty, . . . . . D. I CANVAS, . . . . . . 2 CAPS, . . . . . . . . . I "Percussion, . . . . D. I

CAPSTANS, . . . . . . . 3 CARBOYS, empty, . . O. R., I CARDAMOM SEEDS, • . . . I CARDS, Cattle, Machine, or Playing, I CARPENTER WORK, not otherwise specified,

CARPETING, .

CARPET BAGS,

" CHAIN or LINING, . 2

CARRIAGES, all kinds (see estimated weights), . . . . . . . I

CARRIAGE SPRINGS \& AXLES, 2

CARROTS, . . . . . . . 3

CARS, 8-wheel Passenger, hauled in trains, 20 cents per mile; no charge less than $\$ 6.00$. 8-wheel House, Gondola or Platforms, 15 cents per mile; no charge less than $\$ 4.00$. 3-wheel Coal or Lime Cars, to cents per mile; no charge less than $\$ 2.50$.

CARS, Street Railway, on Platforms, (see estimated weights), . . . 2

CAR SPRINGS, Rubber, in boxes, 3 " " Volute or Iron, . 3 " " in bundles, . . 2 "WHEELS and AXLES, . . 4 
CARTRIDGES, (see Conditions, Rule No. 2),

CASKS, empty (see estimated weight on hhds.),

CASSIA,

CASTILE SOAP,

CASTINGS, Iron, heavy and plain, 3

" light and loose, . . I

" broken, . . . . . 4

" in boxes or casks, . 4

CAST IRON GRAIN MILLS, . . 2 " “ PIPE, Gas or Water, 4

CASTOR OIL, in cans or cases, . I

CATSUP, in wood, . . . . . 2 " in glass, packed, O. R., I

CATTLE (see estimated weights of Live Stock), . . . . . . . 2

CATTLE, in full car loads (see estimated weights of Live Stock), - 4

CAUSTIC SODA, . • . . • . 3

CEDAR WARE,

"WOOD or LUMBER, . 3

CEMENT,

CHAFF,

CHAINS, loose,

66

in casks,

CHAIN CABLES

“ PUMPS,

CHAIRS, boxed, valuable or large, D. I “ not boxed, common, in bundles,

CHAIR STUFF, packed and finished,

CHAIR STUFF, in rough,

CHAMPAGNE, in baskets or cases, I

CHANDELIERS, only received boxed,

CHARCOAL,

CHEESE, boxed,

$\begin{array}{llll}\text { “ loose, . . O. R., } & \text { D. } 1 \\ \text { “ PRESSES, } & \cdot & \cdot & { }^{2} \\ \text { “ SAFES, . } & . & . & \text { D. } ~\end{array}$

CHERRIES, dried, . . . . . 2

“ green, prepared, O.R., I CHESTNUTS, . . . . . . . I CHEWING GUM, in cases, . . I CHICCORY, 3

CHICKENS, alive, in coops, prepaid, . . . . O. R., D. I CHICKENS, dressed, prepaid, O. R., I CHICKEN COOPS (see empties),

I $1 / 2$ I

CHILDREN'S SLEDS, WAGONS, and VEIOCIPEDES, . . . D. I CHINA WARE, . . . . . . I CHLORIDE OF LIME, large quantities, . . . . . . . . . 3

CHLORIDE OF LIME, in jars or packages, .

CHOCOLATE, . . . . . . 2 CHROME, . . . . . . . 3

CHROME ORE, . . . . . . 4 CHURCH ORGANS, knocked down and packed, . . . . . . . I CHURNS, . . . . . $\mathrm{I}^{\mathrm{I} / 2} \mathrm{I}$ CIDER, in wood, . . . . . . 3 " in glass or stoneware, packed, . . . . . . . . . . I CIDER MILLS and PRESSES, . I CIGARS, only received in cases, D. I CINDERS, in car loads, . . . . 4 CIRCUSES may charter cars, each car to be estimated at 20,000 lbs.; they to load and unload at O. R., prepaid,

CISTERNS, iron or wood, . . I $1 / 2$ I CITRON, dried, in boxes,

$$
\text { " green, prepaid, }
$$

O. R., I

CLAMS, prepaid,

CLAY, in car loads, . . . . . 4

CLOCKS and WEIGHTS, . . . I

CLOTHES FRAMES, . . . . I

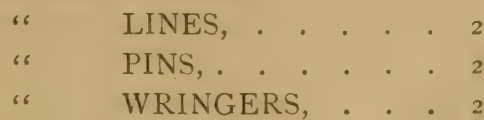

Chilled Rolls. 
CLOTHING, ready-made,

CLOVER SEED,

CLOVES,

CLOVE STEMS, in sacks,

COACHES (see estimated weights of

Carriages),

COACH STUFF,

COAL,

" Bituminous,

COAL OIL, Crude, less than car loads, . . . . . O. R., 2 COAL OIL, Crude, in full car loads, 4

" " Refined, " " 3 " " Refined, less than car loads,

COAL TAR, only carried by special contract,

COAL HODS and SCUTTLES, . 2

"SCREENS, . . . . . I

COBALT, . . . . . . . 2

COB MILLS, . . . . . . 2

COCHINEAL, . . . . . . . I COCOA, .

"m MATTING, . .... 3

" NUTS, in barrels or boxes, 4 CODFISH, dried or pickled, . . 4 COFFEE,

" Condensed or Extract, . 2

" MILLS, . . . . . . 2

COFFINS and CASES, Metallic, . I

" " Wooden, D. I

COKE, . . . . , . . . . 4

COILLARS, Horse, . . . . I

COMBS, in cases, . . . . . . I

COMPOSITION ROOFING, · 3

COMPOST, same as Manure, . . 4

CONCENTRATED LYE, . • • 4

CONDENSED MILK or MEAT, in

cases,

CONFECTIONERY, . . . . . I

CONGRESS and BEDFORD WA-

TER, in wood,
CONGRESS and BEDFORD WA-

TER, in bottles, packed, O. R., I COPPER, manufactured, released,. 3

" rough or cast, . . . 3

COPPERAS, . . . . . . . 4

COPYING PRESSES, • . . . I

CORDAGE, . . . . . . . . 4

CORDIALS, in cases, . . . . . I

CORD WOOD (see Wood, estimated

weights, any quantity), . . . . 4

CORIANDER SEED, • • . . I

CORKS, . . . . . . . D. I

CORN, Shelled, . . . . . . 4

" Green, prepaid, . O.R., I

“ HUSKS, pressed in bales, full

car loads (see estimated weights), 3

CORN HUSKS, pressed in bales, less

than car loads, . . . . . . I

CORN MEAL, . . . . . . . 3

" PLANTERS, . . . . . I

" POPPERS, . . . . . D. I

" SHELLERS, . . . . . I

COTTON, in bales, . . . . . 2

" Compressed, . . . . 3

" loose, in sacks, . . . I

" DUCK, in bales, . . . 2

" GINS, . . . . . . I

" PICKERS, . . . . . I

" SEED, . . . . . 2

" " OIL, . . . . 2

"WASTE and YARN, in

sacks, loose, . . . . . . . . I

COTTON WASTE and YARN, in

bales, pressed, . . . . . . 3

COVERS and SIEVES, . . . . I

CRACKERS and CAKES (see esti-

mated weights), . . . . . . I

CRACKLINGS, . • • • • . 4

CRADLES, Children's, . . D. I

" Grain, . • • • • • I

CRABS, prepaid,. . . . . O. R., I 
CRABS, Soft, prepaid, . O. R., II/2 I

CRATES, empty, berry, new (see estimated weights),

CRATES, empty, berry, new, in full car loads (see estimated weights), 3

CREAM TARTAR, in boxes or kegs, I CREOSOTE,

CROCKERY WARE, well packed, 4

CROSS TIES (see estimated weights),

\section{D}

DAIRY SALT, in sacks and barrels only,

DAIRY SALT, in sacks and barrels only, in car loads,

DATES, in mats,

DECK LIGHTS, packed, . . . I

DEMIJOHNS, empty or full, only received well packed, O. R., II $1 / 2$ I

DEER SKINS, in bales, . . . . I

DESICCATED MEATS and VEGETABLES, .

DESICCATED MEATS and VEGETABLES, in car loads,

DINKEY CARS (see estimated weights),

EARTH PAINT,

EARTHEN or STONEWARE,

EBONY and EBONY GOODS,

EGGS, in barrels or boxes (see estimated weights), . . . O. R.,

EMERY, . . . . . . . . 2

EMPTIES, bags, barrels or boxes in which freight has been carried, will be returned free at O.R.; but if receipts are given, or they are regularly manifested, freight will be charged on actual weight at . I ENGINES, 28 feet long and over, . I

$\begin{array}{lll} & \text { under } 28 \text { feet long, . . } & 2 \\ & \text { in pieces or packed, . } & 2\end{array}$

CROW-BARS, . . . . . . . 4 CRUCIBLES, Black Lead or Earthen, . . . . . . O. R., 2 CRUCIBLES, Metallic, . . . 3 CUCUMBERS, green, prepaid, . I " pickled, in casks, . 2 CULTIVATORS, . . . . . . I CURRANTS, dried, . . . . . 2 " green, prepaid, O.R., I CUTLERY, . . . . . . . . I

DISINFECTING POWDERS, . . 2 DOMESTICS, . . . . . . 2 DOOR FRAMES, . . . . II I 2 I DOORS, loose, . . . . . . . I " in packages, . . . . . 2

DRIED FRUITS, not otherwise specified, . . . . . . . . 3 DRUGS, not otherwise specified, . I DRUMS, . . . . . . . . D. I DRY GOODS, not otherwise specified, DUCK, in bales, . . . . . . 2

DYE WOODS and STUFFS, not otherwise specified, . . . . 3

E

ENGINES, Fire, Hand or Steam, . I “ Steam, portable, . . I " Caloric, . . . . . I ENGRAVINGS, only received well packed,. . . . . O. R., D. I EPSOM SALTS, . . . . . . 3 ESSENCES, in wood, . . . . 2 “ in glass, packed, O.R., I EVAPORATORS, . . : . . . I EXCELSIOR, in bales, . . I I $1 / 2$ I EXIRACT COFFEE, . . . 3

" Hemlock Bark, in cases, 3

“ Logwood, . . . . 3

" Dandelion, . . . . I 
FANCY GOODS, boxed, not otherwise specified, FANNING MILIS, FANS, Palm Leaf, in cases, . . D. I FARINA,

FARM MILLS,

" SLEDS,

“ WAGONS (set up, see Carriages), in pieces, . . . . . I FAUCETS, Brass or Pewter, . . 2 " Wood, in barrels, . . I FEATHERS, . . . . . D. I FEED,

" CUTTERS,

FELDSPAR, FELTING, Boiler,

$$
\text { " Roofing, . }
$$

FELLOES, in bundles,

$$
\text { " in rough, . }
$$

FENCE RAILS and POSTS (see

Lumber and estimated weights), . FENCE WIRE, FERTILIZERS, FIGS, in drums, FILES, in cases, FIRE ARMS, packed in cases, . . I

"BRICK, incar loats, . . . 4 " CI,AY, in car loads, . . . 4 " CRACKERS, (same as FireWorks).

FIRE IRONS,

"WORKS, only by special contract (see Rule 2 of Conditions). FISH, dried, in bundles, . . . . 4 " fresh, prepaid, . . O. R., I

\section{$F_{1}$} FISH, salted, in barrels, . . . . 4 2. FLAX, in bales or bundles, . . . 2 FLAXSEED, . . . . . . 2 FLINTS, .

" ground,

FLOCKS, in sacks, . 3 FLOUR, in sacks, . . . . . 3 " in full car loads, . . . 4 " in barrels, in lots of ro or more, at one shipment, . . . 4 FLUES, Boiler, . . . . . . 2 FORGES, Portable, . . . . . I FORKS, Hay and Manure . . . 2 FOWLS, alive, in coops, . . . D. I FRAMES, Lookıng-Glass and Picture, not received unless boxed, O. R., . . . . . . . . D. I FROGS, Railroad, . . . . . 4 FRUIT, canned, . . . . . . 3 " in car loads, . . . . 4 " dried, not otherwise specified, . . . . . . . . 3 FRUIT, green, not otherwise specified, prepaid, . . . O. R., I FRUIT JARS, packed, . O. R., $\$ 3$. FURNITURE, new, boxed or matted, (see estimated weights), . . I FURNITURE, new, not boxed or matted, (see estimated weights), O. R., . . . . . . . D. $\mathbf{r}$ FURNITURE, second-hand or low priced, (see estimated weights), .. 2 FURS, not received unless boxed, D. I FUSE, Safety, well packed, . . . I FUSTIC,

\section{G}

GAMBIA, GAMBOGE, GAME, prepaid, 
Inooturing ô. Plate.

GAS PIPES, Cast Iron,

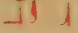

"TUBING, in bundles or cases, 2

" RETORTS, . . . O. R., 2

" TAR, only received by special contract.

GASOMETERS, small, set up, . D. I

66 large, in pieces, . I

GASOLINE, . . . . O. R., I

GELATINE,

GERMAN SILVER and GERMAN SILVER GOODS, . . . . . I GINGER,

GINSENG, in water-tight casks, . 2

GLASSWARE, well packed, . . . I

GLASS, Window, • . . • . 4

GLAUBER SALTS, in barrels, . . 3

" " in small quanti-

ties,

GLOVES, in cases, .

GLUE, .

"Pieces,

GLYCERINE,

GOAT SKINS, pressed in bales, . 2

" " in bundles, . . . I

GOATS, same as Sheep (see estima-

mated weights), . . . . . 2

GOOSEBERRIES, green, prepaid,

O. R., • . . . . . . . . I

GRAIN, not otherwise specified, . 4

" DRILLS, . . . . . . I

“ MILLS,
GRAINS, Brewers', (see estimated weights),

GRAPES, prepaid, . . . O. R., I GRASS SEED, . . • . . . . 2 GRAVEL, . . . . . . . . 4 " ROOFING, in barrels, . 4 GREASE, in barrels, . . . . 4 GREEN CORN, prepaid, O.R., I GRINDSTONES, . . . . . 3 GRITS, . . . . . . . . 2 GROCERIES, not otherwise specified, .

GUANO, . . . . . . . . 4

GUM CAMPHOR, . . . . . I

" COPAL, . . . . . . . I

" KOWRIE, . . . . . . 3

" SHELLAC, . . . . . 2

GUNNY BAGS, in bales, . . . . 4

GUNS, in cases, . . . . . . . I

GUN BARRELS, in cases, . . . 2

" CARRIAGES, . . . . . I

"STOCKS, finished and pack-

ed, . . . . . . . . . 2

GUN STOCKS, in rough, . . . 3

GUNPOWDER only received by special contract, and then subject, in all cases, to the conditions prescribed by the laws of the State in which it is to be transported.

GUTTA PERCHA, in bales, . . 2

" " GOODS, . . I

$\mathrm{H}$

HAIR, in sacks or barrels, Plasterers', I " " " Upholsterers', .

D. I

HALIBUT, smoked,

HAMES,

HAMMERS, .

$$
\text { " Steam or Trip, }
$$

HAMS, in casks,

HAND CARS, (see estimated weights),

HANDLES, Axe, Fork, Hoe, \&c., in bundles,

HANDSPIKES,

HARD BREAD (see Bread in esti-

mated weights),

HARDIVARE, not otherwise speci-

fied, . 
HARNESS, not received loose, . . I HARROWS, HATS and CAPS, . . . . . . I $\mathrm{HAY}$, only received pressed in bales, I " " 6 " 6

full car loads(see estimated weights), 3 HAY CUTTERS,

" PRESSES, knocked down, . 2

“ " set up, . . . . I

HAVERSACKS, . . . . . . I HEADING (see Lumber, in estima-

ted weights), . HEMP, in bales,

$\begin{array}{lllllll} & \text { CARPET, . . } & \text {. } & \text {. } & . & \text { I } \\ & \text { MACHINES, } & . & . & . & . & 2 \\ & \text { SEED, . . } & \text {. } & \text {. } & \text {. } & \text {. } & 2\end{array}$

HERBS, dried, in bales or boxes, . I HERRING, in boxes or kegs, . . 2 HICKORY NUTS,

HIDES, green (see estimated weights),

HIDES, dry (see estimated weights), I " pressed in bales,. . . . 3 HIGHWINES, in wood, . . . . I HINGES and HOOKS, HOBBY HORSES, . . O. R., D. I HOES, in bundles,

HOGS, alive (see estimated weights of Live Stock),

HOGS, alive, in car loads (see estimated weights of Live Stock),

4
HOGS, dressed, prepaid, O. R., I HOGSHEADS, empty, (see estimated weights), .

HOLLOW WARE, O R HOMINY, . . . . . 4 HONEY, . . . . . . . . . I HOOFS, HORNS and GLUE PIECES, . . . . . . . 3 HOOPS and HOOP POLES, (see

Lumber, in estimated weights), . 4 HOOP IRON, in bundles, . . . 3 HOPS, in bales, . . . . . . 2 HORSES, (see estimated weights of

Live Stock), . . . . . . . 2 HORSES, (see estimated weights of

Live Stock), in full car loads, . 4 HORSE POWERS, . . . . . I

" RAKES, . . . . . . I

" SHOES, in kegs or packages, . . . . . . . . . 3 HORSE CARS, (see cars), . . . 2 " RADISH, (in barrels or boxes), . . . . . . . . • 3 HORSE RADISH, (prepared in cases), . • . . . . . . . 2 HOSE, Rubber or leather, . . . 2 HOUSEHOLD GOODS, not Furniture, . . . . . O. R., 2 HUBS and SPOKES, (see Lumber, in estimated weights), . . . . 4 HUSKS, same as Hay.
ICE, prepaid, . . . . . O. R., 3 INDIA RUBBER, crude, . . . . 2 INK, in wood, GOODS, . • I " in glass or stoneware, packed, I INSULATORS, . . . . . . . 2 IRON NUTS and BOLTS, . . . 3
IRON, old broken or scrap, . • • 4 " ORE, . . . . . . . 4 " Pig or Bloom, . . . . . 4 " Bar or Boiler, . . . . . 4 " PIPE, Gas or Water, . . . 4 " RAILING, . . . . . . 2 “ Railroad, . . . . . . 4 
IRON, Rail Road, in car loads, IRON, Rail Road, Chairs and Fish

$$
\begin{aligned}
& \text { Plates, . . . . . } 4 \\
& \text { " Roofing, . . . . . } 3 \\
& \text { “Safes, }
\end{aligned}
$$

IRON, Sheet or Hoop, . . . . 2 "Shutters, . . . . . . I " Sinks, . • . • • • • 2 ISINGLASS, . . . . . . . 2 IVORY AND IVORY GOODS, . I IVORY BLACK, . . . . . . I
JACK SCREWS, . . . . . . 2 JAPAN WARE, · · · . I I I $/ 2$ I

" VARNISH, . . . . . 2 JOINT BLOCKS, .
JOINER WORK, except Doors, Blinds, Sash and Shutters, . . . 2 JUNIPER BERRIES, . . . . 2 JUNK AND JUTE, . . . . . 3

\section{K}

KAOLIN, KEGS, empty beer (see table of estimated weights), KEROSENE,
KETTLES, . . . . . . . D. I KIPS, loose, . . . . . . . . I " in rolls or cases, . . . . 2 KNAPSACKS, . . . . . . I

LLeod diry.

LADDERS, not over 28 feet long, . I 66 66 $66 \quad 66 \quad 66$ D. 2

LAMBS (see Sheep, in estimated weights of Live Stock),

LAMBS (see Sheep, in estimated weights of Live Stock), in car loads,

LAMP BLACK, 1). I " SHADES, in cases, . . D. I

LAMPS,

LANTERNS

LARD, in barrels, . " in crocks, " Oil, . " " I

LATH (see Lumber, in estimated weights), . . . . . . . . 4

LAUREL ROOTS, less than car load, 2 LEAD, BLACK, . . . . . . 3 " Pipe,
LEAD, Sheet,

"White or Red, dry or ground in oil, . . . . . . . . . 2

LEAD, White or Red, dry or ground in oil, in full car loads, . . . 4 LEATHER, loose, . . . . . . I " in rolls or cases, . . 2 " scraps or shavings, only in full car loads, unless boxed, - 4 LEMONS, . . . . . . . . I LEMON SYRUP, . . . . . . I LIGHTNING RODS, in bnndles, . 3 LIGNUM VITÆ, manufactured, . 2 " " not manufactured, 3 LIME, in small quantities, . . . 3 LINEN AND LINEN GOODS, . I LINSEED, . . . . . . . 2 " OIL, . . . . . 3 LENTILS, . . . . . . . . 2 
LIQUORS, in wood, not otherwise specified,

LIQUORS, in glass, not otherwise specified (packed), . . . O. R., I

LIQUORICE,

LITHARGE,

LITHOGRAPHIC STONE, O. R., I

LIVE STOCK (see estimated weights), less than a car load, . 2

LIVE STOCK (see estimated weights), in full car loads, . . 4

LOAF SUGAR, . . . . . . 2

LOCOMOTIVES, hauled in trains, 40 cents per mile; no charge less than $\$ 5.00$.
LOCOMOTIVE TENDERS, hauled

in trains, 15 cents per mile; no

charge less than $\$ 3.00$.

LOCOMOTIVES, other gauges, on

Platform cars, estimated weight, . 4 LOCOMOTIVE TIRE, • • • • 4

HEAD LIGHTS,

boxed, . . . . . . . . I

LOGS (see Lumber, in estimated weights), . . . . . • . 4

LOGWOOD, ground, in barrels, . 2 “ EXTRACT, . . $z^{3}$

LUMBER (see estimated weights), 4 LETTUCE, green, prepaid, O. R., I

\section{Tíaclecral}

MACARONI,

M A C H INERY, disconnected or boxed,

MACHINE CASTINGS, heavy, . 3 " 66 light,

MADDER,

MAHOGANY BOARDS AND PLANKS, .

MAHOGANY LOGS,

“"

“

VENEER, in boxes,

" in bundles, $\mathrm{I}$

MALT,

66

Grains,

MANGLES, set up,

66

$\mathrm{knocked}$ down and

boxed,

MANILLA,

MANGANESE,

MANURE,

MAPLE SUGAR,

MARBLE MANTELS, rough or finished, if not boxed, . . O. R., I MARBLE MANTELS, rough or finished, boxed,

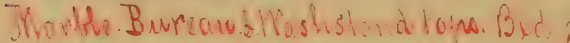

MARBLE MONUMENTS, over

I, 000 pounds in weight, packed, I MARBLE MONUMENTS, rough or

finished, less than I,000 lbs., boxed, 2 MARBLE MONUMENTS, rough or finished, any size, if not packed,. I MARBLE, rough and building, . 4 MARBLES, in boxes or casks, . . 2 MARBLE DUST, . . . . . . 4 MARL, same as Manure, . . . . 4 MATCHES (see Conditions, Rule 2),

D. I

MATCH STICKS, in cases, . . . 3 MATTRESSES, MATS, MATTING, COCOA, " STRAW,

MEAL, in barrels, . . . . . . 3

" in sacks, . . . . . . 2

" " " in full car loads, • 4 " " barrels, in lots of 10 or more, MEASURES, in nests, 
MEATS, fresh, prepaid, . O. R., I " salt, dry or smoked, . . 3 MEDICINES, not otherwise specified, MELODEONS, only received boxed, I MELONS, prepaid, only received in large quantities, O. R., I MELONS, prepaid, in car loads, . 2 MENAGERIES, same as circus, . 2 METALLIC COFFINS, . • • • I METALLIC PAINTS, . . . . 2 METERS, gas or water, in boxes, . 2 MICA,

MILK, by special arrangement.

“ CONDENSED, in cases, . 2 MILLS, portable, on frames, . . I MILLET, MILLL FEED, MILL STONES, rough, 66 " finished,

MINERAL WATERS, in bottles, packed,
MOLASSES,

MOSS, loose in sacks, .

- 4

D. I " pressed in bales, . . . . I MOULDINGS, only received well packed, O. R., D. I MOULDING AND IRONING BOARDS, in packages, . . . 2 MOWING MACHINES, . . . . I MOWERS \& REAPERS, combined, I MULES, (see live stock and estimated weights),

MULES, (see live stock and estimated weights), in car loads, . . . . 4 MUSICAL INSTRUMENTS, not otherwise specified, . . . . D. I MOROCCO, in rolls, . . . . . I " in cases, . . . . . 2 MURIATE OF IRON, . . . . 2 " "POTASH, . . . 2

MUSKETS, in cases, . . . . . I MUSTARD, ground, in casks or boxes, . . . . . . . . . 2 MUSTARD SEED, . . . . 2 MUTTON, fresh, prepaid, O. R., I

NAILS, in kegs,

NAIL RODS,

NAPHTHA, (see Conditions, Rule 2),

O. R., NICKEL, manufactured, “ ORE, NITRATE LEAD, 66 SILVER,

4


OIL, Kerosene and Coal, (see Con'ditions, Rule 2)

OIL, Kerosene and Coal, in full car loads, OIL, Coal, Crude, in full car loads, " " " less than full car loads, . OIL, Whale, Lard and Linseed, . 3 OKRA, prepaid, O. R., I OMNIBUSSES, (see Carriages, in estimated weights), . ONIONS, early, bunches, in crates, boxes, \&c., prepaid,

O. R., 2
Jincons बiv $\omega_{1}$

ONIONS, late, in barrels, ORANGES, . . . . O R ORDNANCE STORES, . • . D. I ORNAMENTS, Plaster of Paris, securely packed, . . . O. R., D. I OSIERS, boxes, bales or bundles, . 2 OX BOWS AND YOKES, . . . 2 OYSTERS, cans and kegs, prepaid,

O. R., .

OYSTERS, in shell, prepaid, O. R., 3 Shells, (in car loads, same

as manures),

OXALIC ACID,
PAILS, wooden, in bundles, . I I I I I PAINTINGS, only received well packed, . . . . . O. R., D. I PAINTS, not otherwise specified, . 2 PALM LEAF, in sacks or cases, . I
" " FANS, in cases, . D. I
" OIL, .
" SOAP,

PANORAMAS, only received well packed, O. R., D. I PAPER BOXES, in bundles, . D. I

"HANGINGS, in bundles, . I " " in boxes, . 2 " PRINTING, Heavy Brown or Straw,

PAPER, PRINTING, Heavy Brown or Straw, in car loads, . . . . 3

PAPER STOCK, . . . . . . 4

"WRITING, in cases, . . I

PAPIER MACHE GOODS, · · I

PARAFFINE, . . • • . . . 2

PASSENGER CARS, (see cars), . 2

PASTE BOARD, in bundles, . . 2

" " in cases, . . • 3

PEACHES, green, prepaid, O. R., I " dried, . . . . . 2 PEACH STONES, in sacks, . . 2
PEANUTS, . . . . . . . 2

PEARS, green, prepaid, . O. R., I " dried, . . . . . . . 2 PEAS AND BEANS, dried, . . . 3 " " " green, prepaid, O. R., • . • . . . . • I PEAT, . . . . . . . 4 PEI,TRIES, only received in casks,

barrels or boxes, . . . . . . I PENCILS, Lead, in cases, . . . I "Slate, " ". . . . 2 PENS, in cases, . . . . . . . I PEPPER, in bags, . . . . . . 3 " in casks or boxes, . . 2 " Sauce, in glass, packed, O. R., . . . . . . . . . I PERAMBULATORS, Children's, D. I PERCUSSION CAPS, . . . D. I PETROLEUM, Crude, in full car loads, . . . . . . . . . 4 PETROLEUM, Crude, less than full car loads, . . . . . . . . 2 PE'TROLEUM, Refined, less than full car loads, (see Conditions, Rule 2), PETROLEUM, Refined, in full car loads, 
PHOSPHATES,

PHOSPHORUS (see Rule 2 of Conditions),

D. I

PIANOS, only received boxed at O.R., I PICKETS, see Lumber in estimated weights,

PICTURES, same as Paintings, O. R., . . . . . . . . D. I PICTURE FRAMES, only received boxed, . . . . . O. R., D. I PICKLES \& PRESERVES, in casks, 2 “ in glass,

packed, PIG IRON,

PIGS, SHEEP, LAMBS, \&c., alive in boxes,

PILES, see Telegraph Poles in estimated weights,

PILL BOXES, in casks or boxes, D. I PILLOWS, Feather, Hair, \&c., in sacks,

D. I PINE APPLES, prepaid, . O. R., I PINS, in original packages, . . . I PIPES, Clay or Wood, . . . . 2 PI'TCH,

PLANTS AND POTS, in boxes on'y, prepaid, . ... O. R., D. I PLANTS, in bbls., prepaid, O.R., I I I I I PLANING MACHINES,

PLASTER, same as Phosphates,

PLATE GLASS, only received well packed in boxes, . . O. R., D. I PLATED GOODS OR WARE, - I PLOW HANDLES AND BEAMS, finished, in bundles,

PLOW HANDLES AND BEAMS, loose and rough, PLOWS AND CULTIVATORS, . I PLUMS, green, prepaid, . . O. R., I
PLUMBERS' MATERIALS, . . 2 PORCELAIN WARE, in hhds, or

boxes,

PORK, fresh, prepaid, . . O. R., I

" salted, in barrels,

" " c loose, $-\cdot 0 \cdot 0 \cdot 0$

PORTER, in wood, . . . . . 3

" in glass or stoneware,

packed, .

POSTS AND RAILS (see estimated

weights of Lumber), . POTASH, in casks,

" in boxes,

POTATOES, Irish or Sweet (see es-

timated weights), . . . O. R., 4 POTATO HOOKS, in bundles, . I POUDRETTE, same as Phosphates, 4 POULTRY, alive in coops, prepaid,

O. R.

D. 1

POULTRY, dressed, prepaid, O.R., I PRINTERS' INK, in wood, . . 2 PRINTING PRESSES, set up and boxed,

PRINTING PRESSES, knocked

down and packed, . . . . . 2 PRINT CLOTHS, . . . . . . I PRUNES, in boxes or casks, . . 2 PRUSSIATE OF POTASH, . . $\quad 2$ PUMPKINS, common, small quantities, in boxes, casks or crates, O. R., 2 PUMPKINS, loose (only in car loads), . . . . . O. R., 3 PUMICE STONE, . . . . . 2 PUMPS, Iron, . . . . . . . I

“ Copper, in cases, . . . I
" Booden, . . . . . . I
" Blocks, Brakes or Tubing, wooden,

2

PUMPS, Blocks, Brakes or Tubing,

wooden, in large quantities, . . 3 PUTTY, in kegs, 


\section{Q}

QUEENSWARE, . . . . . 4 QUILLS, in boxes, . . . . I $\begin{array}{llllll}\text { QUERCITRON, in casks, . } & \cdot & \cdot & 3 & \text { QUINCES, . . . . . . . O. R., I } \\ \text { QUICKSILVER, in iron flasks, } & . & \text { I } & \text {. }\end{array}$

$\mathbf{R}$

RADISHES, prepaid, • . O. R., I RAGS, in bales, pressed, . . . . 4 " in sacks, loose, . . . . 2 RAII, ROAD CHAIRS, SPIKE \& FISH PLATES, RAIL ROAD FROGS, 66 IRON, .

RAISINS, in boxes (not strapped), I

" " " cased or strapped, 2 RAKES, Hand or Horse, . . . I RAPE SEED,

RAT TRAPS, in packages or cases, I RATTAN, in bundles,

REAPERS (see agricultural implements), . REFRIGERATORS, . REGISTERS, Air, Steam, \&c., . I RESIDUUM, from Oil Refineries, in car loads only, . . . . . 4 RETORTS, Clay, . . . O. R., I "Iron, . . . . . 2

RIBBONS \& FLOWERS, in boxes,

RICE, in bags, D. I " " in barrels or tierces, . . . 4 RIFLES,

S.ADDLE TREES, SADDLERY, SAD IRONS, SAFES, Iron,

" CHEESE, MEAT, MILK or BREAD,
RIFLES, Scythe, • . • • . . 2 RIGGING, for vessels, . . . . 3 RIVETS, Brass, Copper and Iron, . 2 ROCKING CHAIRS (see Furniture, . estimated weights), . . • • . I ROLLING PINS, in boxes, . . . $z$ ROOFING MATERIAL, in boxes or rolls, ROOFING IRON,

$$
\text { " Composition,. . . . } 3
$$

ROPE, heavy, in coils, . . . . 4 ROSEWOOD, LOGS, BOARDS, or

PLANKS, . . . . . . . 3 ROSEWOOD VENEERS, in boxes, 2 in bdls., I ROSIN, . . . . . . . 4 ROTTEN STONE, . . . . . 2 RUBBER, Belting or Hose, . . . 2 " Car Springs, in boxes, . 3 " Crude, . . . . . . 2 " Goods, . . . . . . I " Packing, . . . . . 2 RUGS, . . . . . . . . . I RUM, Domestic or Foreign, . . . I RUSSIA BRISTLES, . . . . . I RYE, . . . . . . . : . 4

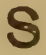


SALT, eoarse, floose, only in-car. toads, ) .

SAIT, DAIRY, in sacks-and-barrets-4 SALTPETRE,

SALTS, BLEACHING,

" EPSOM,

"GLAUBER, in small quan-

tities,

SALTS, GLAUBER, in barrels, . 3

" ROCHELLE -

SAND, loose, only in car loads, . 4

SAND PAPER, in bundles, . . . 2

" " in cases, . . . . 2

" SCREENS, . . . . . . I

SARDINES, in cases, . . . . . 2

SASH, in bundles, unglazed, . I I 12 I

" " " glazed, . . D. I

SAWDUST, loose, only in car loads, 4 SAWS, boxed, . . . . . . . 2 SCALES AND BEAMS, boxed, . 2 O. R., • • • • • • • . . I

SCHOOL FURNITURE, seats, desks, \&c., set up, . . O. R., I SCHOOL FURNITURE, in car loads, (same as furniture), O. R., I SCHOOL FURNITURE, knocked down and packed,

SCHOOL SLATES, in cases, . . 3 SCOOPS,

SCRAPERS, ROAD OR DIRT, . 2 SCREENINGS, COAL, . . . . 4 SCREENINGS, GRAIN, · . 3 SCREWS, in boxes, Iron, . . . 2 " " "Wood,. . . 2 SCYTHES, in boxes or bundles, . 2 SCYTHES, Snaths, in boxes or bdils., I "Stones and Rifles, in boxes,

SEEDS, Canary and Garden,

" Clover, Grass, \&c., - * SEED DRILLS,
SEWING MACHINES, boxed, (see estimated weights), . . OR I SEWING MACHINES, not boxed,

O. R., . • . . . . . D. I

SHAVINGS, in bales, for paper

stock, . . . . . . . . . 4

SHEEP, (see Live Stock in estimated

weights), . . . . . . . 2

SHEEP, in car loads, . . . . 4

" SKINS, in packages only, 2

" SHEARS, in boxes, . . I

SHEATHING METAL, . . . . 2

SHELL, empty, . . . . . . 3

" loaded, only by special con-

tract, . . . . . . . . . I

SHINGLES, (see estimated weights of

Lumber), . . . . . . . . 4

SHINGLE MACHINES, . . . I

SHIP TIMBER, (see Lumber in esti-

mated weights), . . . . . 4

SHODDY, in sacks, loose, . . . I

" in bales, pressed, . . 3

SHOES, . . . . . . . . . I

SHOE BLACKING, . . . . . 4

" NAILS, in boxes, . . . 3

" PEGS, in barrels,. . . . 2

SHOOKS, (see estimated weights of

lumber), . . . . . . . . 4

SHORTS AND SHIP STUFF, . . 3

SHOT, in bags, . . . . . . . I

" packed in kegs or boxes, . 2 SHOVELS AND SPADES, in bdls., 2

" " in car loads, 3

SHOW CASES, only received boxed

at . . . . . . O. R., D. I

SHRUBBERY, in car loads, (see es-

timated weights), . . O. R., 2

SHRUBBERY, less than car loads,

prepaid, (see estimated weights),

O. R., . . . . . . . . . I

SICKLES, in boxes or bundles, . I

SIEVES, in nests, . . . . . . I 
SILICATE OF SODA,

SILKS, only received in boxes, . . I SIZING, . . . . . . . . . 2 SLATE, TILE AND ROOFING, . 4 " MANTELS, rough or finisned, not boxed, . . O. R., I SLATE MANTELS, rough or finished, boxed, . SLA'TE PENCILS, in cases, . . 2 SLEDS, Children's, . . . . D. I " Farm, . . . . . . . I

SLEIGHS, (see estimated weights), I " boxed, . . . . . D. I SMUT MACHINES, . . . . . 2 SNAKE ROOT,

SNUFF, in boxes, barrels or casks, 2

" in jars,

SOAP, Common, Castile and Hard, 5

"Fancy, . . . . . . 2

"Soft, in casks, . . . . . 3

"STONE,. • . • • . . 4

SODA ASH, . . . . . . . 4

"Sup. Carb., . . . . . . 4

" WATER, in Fountains, . . I SOFAS, (see estimated weights, furniture), SULDER, SORGHUM SYRUP, same as Molasses, SORGHUM MILLS, . . . . . I SOUR KROUT', in casks, . . . 3 SPARS, by special contract only. SPELTER, SPERMACETI,$\cdot \cdot \cdot \cdot \cdot \cdot \cdot \cdot{ }^{\prime} \cdot{ }^{\prime}$ SPICES, not otherwise specified, . I SPIKES, Rail Road, . . . . . 4 SPINACH, prepaid, . . O R., I SPINNING JENNYS, Machines or

Wheels, O. R., I SPIRITS, not otherwis specified, . I " TURPENTINE, O.R., I SPOKES, (see estimated weights of lumber),
SPONGES, pressed in bales, SPOONS, Iron, in cases, . . . . 2 SPRING BEDS, well packed, • D. I SQUASHES, small quantities, in boxes, casks or crates, . O. R., 2 SQUASHES, loose, only in car loads,

O. R., .

STAGE COACHES, (see estimated

weights of carriages),

STARCH, in boxes,

STATIONERY,

STATUARY, only received boxed,

O. R., • D. I STAVES AND HEADING, (see es-

timated weights of lumber), . . 4 STEAM BOILERS, $28 \mathrm{ft}$. in length

and over, . . . . $\mathrm{I} / 2 \mathrm{2} \mathbf{I}$ STEAM BOILERS, under 28 feet in

length, . . . . . . . . . I STEAM BOILERS, in sectional parts, 2 “ ENGINES, (see Engines).

STEARINE, in hhds., . . . . 3 STEEL, in bars, rods, \&c., . . . 4

" SPRINGS, Wagon, \&rc., . 2 STILLS, Copper, Iron or Tin, . I I $1 / 2$ I STONE, (see estimated weights,

wrought), . . . . . . . 3 STONE, (see estimated weights), . 4 STONE WARE, in packages, O. R., 4 STOVE BLACKING,

" PIPE, in bundles, . . D. I

" PLATES, boxed, . . . I

" " not boxed, O.R., D. I

STOVES AND STOVE FURNI-

TURE, . . . . O. R., I STOVES AND STOVE FURNI-

TURE, in car loads, ' . O. R., I STRAW, pressed in bales, . . . I

" in car loads, (see estimater

weights, not received loose), • • 3 STRAW GOODS, in cases, . . . I 
STRAW BOARD AND PAPER, " car loads, STRAWBERRIES, prepaid，O.R., I STUCCO, in barrels, . . . . . 3 SUGAR, " " boxes or hhds., 4 " in single sacks, . . . . 4 " in loaves, . . . . . 4 " MAPLE, . . . . . 4 " EVAPORATORS, . . . I
SUGAR KETTLES, . • • . . I

" MILLS, • • . . . . I

" OF LEAD, . . . . . I

SULPHATE OF COPPER, . . . 2

" " $"$ SODA, . . . 2

" " $\mathrm{ZINC}$. . . . 2

SULPHUR, in hogsheads or barrels, 3 SUMAC, in sacks, ground, . . . 4 SWITCH FRAMES, . • . • . 3 SYRUPS, Sugar House, Maple, \&c., 4
TACKS, in boxes, . . . . . 2 TALLOW,

TAMARINDS, in kegs or casks, . I TAMPICOS, in bales, pressed, . 3 TANKS, Iron or Wood, . . . I I $/ 2$ I TANNERS' SCRAPS, in packages, 4 TAPES, in cases, . . . . . . I TAPIOCA,

TAR, TARPAULINS,

TARTARIC ACID, TEA, TEAZLES,

TELEGRAPH POLES (see estima-

ted weights), . . . . . . . 4 TELEGRAPH WIRE, . . . . 4 TENTS, . . . . . . . . . I TENT PINS, in boxes or casks, - 3 " POLES, . . . . . . . 2 TERRA COTTA, . . . . . . 3 “JAPONICA, . • . . 3 THEATRICAL SCENERY, packed, O. R., . . . . . . . . $\mathrm{I} 1 / 2 \mathrm{I}$ THREAD, in cases, THRESHING MACHINES (see estimated weights), TICKING, TILE DRAIN, . . . . . O. R., 3 TIMBER (see Lumber), . . . . 4 TIN BLOCK, Pig or Plate, . . . 4
TIN WARE, boxed, . . . . . I " " loose, . . . . D. I " FOIL, in cases, . . . . . I TIRE, LOCOMOTIVE, . . . . 4 "WAGON, . . . . . 2 TOBACCO LEAF, in hogsheads, . 3 “ Manufactured, not otherwise specified, TOBACCO PIPES, . . . . . I TOILET TABLES (see estimated

weights of Furniture), . . . . I TOMATOES, fresh, prepaid, O. R., 2 TOMBSTONES, only received packed, if finished, . . . . . I TOMBSTONES, in rough, packed,

O. R., . TOOLS, Mechanics', in chests, . . I TOW, in bales, . . . . . . . 2 TRAIN OIL, . . · . . . 3 TRAVELING BAGS, in cases, . . I TRAYS, Iron, in cases, . . . . I

"Wooden, in nests, . . . 2 TREES, in car loads, (see estimated weights of Shrubbery), . O. R., 2 TREES, less than car load, prepaid, O. R., TRIPE, in kits, kegs or barrels, . 2 TRUNKS, empty, . . . . . D. : " packed, not baggage, . I 
TUBING, Wood or Iron, not otherwise specified, TUBS, in nests, TURMERIC, TURF, less than a car load, . TURNED STUFF, not otherwise specified, TURN TABLES, in pieces, . . . 3
TURNIPS, early, in barrels or crates, prepaid, . . . . O. R., 2 TURNIPS, late, in barrels, . . . 3 TURPENTINE, . . . O. R., 2 TURTLES, prepaid, . . O. R., I TWINE, in bales or barrels, . . . 2 TYPE, . . . . . . . 2

\section{ULTRAMARINE BLUE, . . . . $\quad 2$ UMBRELLAS, in cases, . . . . I UMBER, dry or ground in oil,. . ${ }_{2}$ -}

\section{V}

VALISES, · . . . . D. I VENISON, prepaid, . . O. R., I VARNISH, not otherwise specified, I VENITIAN BLINDS, well packed, I

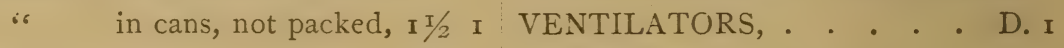
VATS, empty, . . . . . . I I 2 I VERMICELLI, in boxes, . . . I VEAL, fresh, prepaid, . O. R., I VISES, Iron, . . . . . . . 2 VEGETABLE IVORY, rough or manufactured, VEGETABLES, not otherwise specified, VEHICLES, (see Carriages), . . I VELOCIPEDES, . . . . . D. I VENEERING, in boxes, . . . . 2 “ in bundles, . . . I

3.

VINEGAR, . • • • • • • 3 VITRIOL OIL, in full car loads, (see conditions), . . . . . . . I VITRIOL OIL, less than full car loads, (see conditions), . . D. I VITRIOL BLUE, . • • • • • 3 VOLUTE, car springs, \&c., . . . 3

\section{W}

WADDING, in bales, . . . D. I WAGONS, (see estimated weights of WAGON AXLES, Iron, . • . . 2

"BOWS AND FELLOES, in bundles,

WAGON HUBS AND SPOKES, dressed, in bundles, . . . . WAGON HUBS \& SPOKES, rough,

(see Lumber), at estimated weights, 4 WAGON SHAFTS, in bundles, . I carriages), . . . . . . . . I WAGONS, CHILDREN'S, . . I I 1/2 I 2 WARP BEAMS, empty, . . . . I " " full, . . . . 2 2. WARPS, in bales, . . . . . . I WASHBOARDS, Wooden, . . . I I IVASHING MACHINES, . . . I 
WASHING POWDERS OR LIQUIDS, in wood, .

WASTE, in sacks, " in bales, pressed, . . . 4 WATER COOLERS, not received unless boxed, . . . . . . . I WATER PIPE, Iron, • • • 4 WAX, .

WEIGHTS, Iron, on strings or in cases, 3 WELL BUCKETS, . . . . . 2 WHALEBONE, . • . . . . I WHEAT,

WHEELBARROWS, (see estimated weights), • . . . . . . . I WHEELS, CAR, . . . . . 4 "WAGON, in bundles, . 2 WHETS'TONES, in boxes, . . . 2 WHIPS,

WHITE LEAD \& ZINC PAINTS, 4 WHITING, . . . . . . . 4 WHISKEY, . . . . . . . . I WICKING, in bales, . . . . . I WILLOW REEDS, in bundles, . 2 66 WARE,

D. I
WINES, in casks, . . . . . . I " "glass, packed, . O. R., I WINDOW FRAMES, . . . I I/2 I " GLASS, . . . . . 4 WIRE, not otherwise specified, . . 2 " CLOTH, in rolls or cases, . I " ROPE, . . . . . . 3 WOOD, (see estimated weights), 4 " SCREWS, . . . . . 2 WOODEN EAVE TROUGHS, D. I "WARE, . . . . . 2 WOOD, in shapes, not otherwise specified, . . . . . . . . 2 WOOL, pressed, in bales, . . 3 " loose, in sacks, . . . I I $1 / 2$ I WOOLEN GOODS, heavy, in cases, I " " knit, light, in cases, • • • • • • • • . I WOOLEN YARN, in sacks, bales cases, . . . . . . . . rs WRAPPING PAPER, • • • . 2 " " in car loads, 3 WRINGERS, . . . . . • 2

\section{$\mathrm{Y}$}

YARN, in bales, . . . . . 2 YEAST, in Wood, . . O. R., 2 YEAST POWDER, . . . . . 2 YOKES, OX, . . . . . . 2

\section{Z}

ZINC, in bars, . . . . . . . 4 ZINC, OXIDE, . . . . . . 2 " in cases or casks, . . . . . 4 " " PAINTS, dry or ground in oil, 4

" in sheets or rolls, . . . . 2 


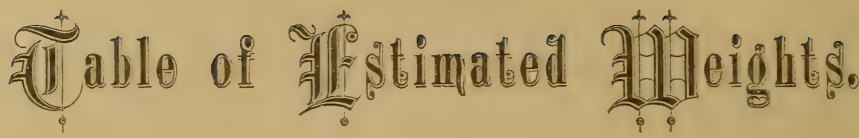

ARTICLES IN THIS TABLE MARKED THUS * WILL NOT BE CARRIED AT A LESS WEIGHT THAN THAT GIVEN, THE PRICE FOR THEIR TRANSPORTATION Being Based UPon their estimated Weights. ARticles NOT SO MARKED WILL ALWAYS BE CARRIED AT ACTUAL WEIGHT WHEN IT CAN BE GIVEN.

*A gricultural imPLEMENTS, per car load, I 2,000 lbs. *AGR IC U L T U RA L IMPLEMENTS, in proportion to space occupied if less than a.car load, but never less than actual weight.

ALCOHOL, per gall. ıolbs., per bbl., . . . . ALE, per bbl., . . . . 350 " APPLES, green, per bush. 60 lbs., per bbl., .. . . 150 " APPLES, dried per bush., $\quad 30$ " ASHES, per. bbl., . . . 450 "

\section{$\mathrm{B}$} BARLEY, per bush.,. . BARK, per cord, 3,000 lbs., 1,000 “ 45 “ ground in hhds. 2,000 lbs., per car load, . . . . I6,000 " *B A R R ELS, empty, beef, beer, pork or oil, each, 8o" *BARRELS, empty halves, beef, pork or oil, each, . *BARRELS,empty flour,each
*BARRELS, empty flour, in car loads, . . . . 1 $2,000 \mathrm{lbs}$. *BOXES, empty, in car loads, I 2,000 " BRICKS, Bath, each, . . 6 " 6

$\begin{array}{ll}\text { " Common, each, } & 5 \text { " } \\ \text { " Fire, each, . . } & 8 \text { " }\end{array}$
BEANS, dried, per bush., 60 " BEEF, Salt, per bbl., . . 300 " BEER, per bbl., . . . 350 " " per keg, . . . 90 " BRAN, per bush., . . . 35 " BRANDY, per gall. ro lbs., per bbl., . . . . 400 " *BREAD, CRACKERS and

CAKES, per bbl., . . 100 " *BROOMS, per doz., . . 50 " BUCKWHEAT, per bush., 45 " BUTTER, salted and packed, per bbl., . . . 300 “

\section{CaLF skins, green, each}

I 2 lbs., dry, each, . . 10 " *CARRIAGES,

$\begin{array}{ccc}\text { " Light, one Horse, } & \text { I,500 " } \\ \text { "Heavy, " “ } & 2,250 \text { " } \\ \text { " } & \text { " two " } & 3,000 \text { " }\end{array}$


CARRIAGES, Heavy one Horse Cart, . r,500 lbs.

" Heavy $\mathrm{Ox}$ Cart, . . . 2,500"

" Stage Coach, Omnibus, very large Wagon or Ambulance, . . 5,000" Sulky, or very light Trotting Buggy, I,000 " CARROTS, per bush.6olbs., per bbl., $150 \%$

*CARS, Street Railway, one alone, . . . . . 9,000"

*CARS, Street Railway, two on one platform car, . I 2,000 " *CHAFF, per bush., . . 25 " *CHARCOAL, per bush., . CIDER, per bbl., . .

CLAMS, per bush. 90 lbs., per bbl.,

CEAY, per cubic foot, .

CLOVER SEED, per bush.,

COAL, per bush. So lbs., per ton,

CHROME ORE, per ton,

COAL OIL or KEROSENE, per bbl.,

*COKE, per bush., . . .

*CORN, in the ear, per bush.,

"Shelled, per bush.,

*CRATES, new empty.berry, per cubic foot 10 lbs., per car load, . . . . . 12,000" CROSS TIES, per cord, . 6,000 " D INKEY CARS, each, . 3,000 “ ${ }^{*} \mathrm{E}$ GGS, per bbl., . . . 200 “

"F EED, per bush., 35 “ FISH, salted, per bbl., . 300 " *FLAX SEED, per bush., . $\quad 56$ "
FLOUR, per bbl., . . . 200 lbs. *FURNITURE, per full car load, Chairs, common, each 25 lbs., valuable, each, 50 "

Rockers, common, each roo lbs., valuable or large, each, . . . . . 250 “

Sofas, common, each $500 \mathrm{lbs}$, valuable or large, each, $800 \%$ Settees, common, each 300 lbs., extra large, each . Bureaus, $300 \mathrm{lbs}$. each, to 600 lbs. each, according to size and quality.

Toilet Tables and Wash Stands, common, each, $100^{66}$ Toilet Tables and Wash Stands, large or valuable, each, . . . . . $25 \mathrm{c}$ "

Lounges, $400 \mathrm{lbs}$. each, to 600 lbs. each.

Bedsteads, from roo lbs. each, to $500 \mathrm{lbs}$. each.

Tables, from roo lbs., to 400 lbs., each.

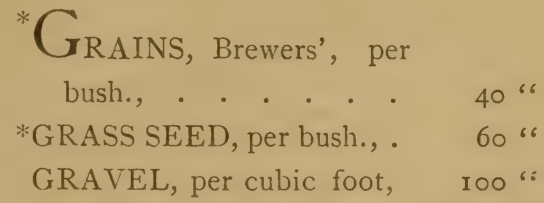

\section{${ }^{*} \mathrm{H}$} AND CARS, each, . 4,000" *HAY, car loads, . . . I0,000 " HIDES, dry, each 35 lbs., green, each, . . . . 85 " *HOGSHEADS, empty, each, 250 " *HUSKS, per car load, . . I0,000 "

I CE, per bush.

$80 \%$ 
IRON ORE, per ton, . $\quad$ 2,240 lbs.

" Pig, per ton, . . 2,240"

"Rail Road, per ton, 2,240 "6

* KEGS, empty Beer, each,

$25^{66}-$

$\mathrm{L}$ ARD, per bbl., . . . $300^{66}$ " Oil, per bbl., 400 "

I.EATHER, per side, . . $\quad 20$."

LIME, per bush. 80 lbs., per

bbl. 250 lbs., per hhd., . I,500 "

LIME, per ton, . . . . 2,240 "6

" per bush. shell 64 lbs.

LINSEED OIL, per bbl., .

$400^{6}$

LIQUORS, per gall. Io lbs., per bbl., . . .

*LIVE STOCK, Cattle,

Horses, Mules, minimum

per car load, . . . . 20,000"6

Sheep, Lambs, minimum per

car load, . . . . . 12,000"

Hogs, Pigs, Calves, minimum

per car load, . . . . I 6,000 "

One Horse, Ox, Cow or

Mule, going alone, . . 3,000 "6

Two Horses, Oxen, Cows or

Mules, going together, . 4,000 "6

Three Horses, Oxen, Cows

or Mules, going together, 4,500 "“

Four to Ten Horses, Oxen,

Cows, or Mules, going to-

gether, each, . . . I,500 "6

Eleven or any greater num-

ber in one car, will be considered a full car load.

Calves, Hogs, Sheep, \&c., will be reckoned at $25^{\circ}$ lbs. each for any number less than forty. Forty or any greater number will be considered a full car load, but more must not

\section{LIVE STOCK-(Continued.)}

be charged for any kind of Live Stock in small quantities at a higher rate than would be charged for a car load going the same distance at Fourth Class Rates.

LUMBER.

Dressing floor, per $\mathbf{I}, 000$ feet,. . . . . 3,500 lbs.

Pickets, large, per I,, 000 pickets, 3,000 lbs., small do., do., . . . . 2,000 "

Plastering Lath, in bundles, per I,000 lath, . . .

Shingling Lath, per $\mathrm{I}, 000$ lineal feet,. . . . . 700 "

Black Walnut, Cherry, Ash, Poplar or Maple, per I,, 00 feet, . . . . . 5,000 "

Hard Pine, dry, per $\mathbf{1}, 000$ feet, . . . . . 4,000 "

Hard Pine, green or wet, per r,o00 feet, . . . . 5,000 “

Oak, green or wet, per $\mathrm{I}, 000$ feet, . . . . 5 5,500 "

Oak, dry, per I, 000 feet, . 5,000 " Gum Wood, green, per $\mathbf{I}, 000$ feet, . . . . . 6,000 "6 Gum Wood, dry, per 1,000 feet, . . . . . 5,000 " Soft Pine, Spruce or Hemlock, dry, per I,000 feet, 2,500 "6 Soft Pine, Spruce or Hemlock, green or wet, per I,000 feet, . . . . 3,500 " Shingles, Cedar or Cypress, long, per $\mathrm{x}, 000$ shingles, I,400 " Shingles, Cedar or Cypress, short, per I, 000 shingles, 900 " Ship Timber, per cubic foot, 60 " 


\section{LUMBER-(Continued.)}

Staves, Heading, Hoop Poles, Fence Rails and Posts, Hubs, Shooks, \&c., at actual weight obtained by a fair average.

Round Logs of any kind, $33^{\mathrm{T} / 3}$ per cent, in advance of rates for same kind of lumber sawed or hewn,per 1,000 feet, mill measurement.

The weights on lumber given above are intended for square edged stuff; if rough edged (or flitch) 5 per cent. more should be added.

${ }^{*} \mathrm{M}$ ALT, per bush., $40 \mathrm{lbs}$. MEAL, per busin., . . . 48 “ MEAT, salted, per bbl., 300 " MILK, per gall., . . . . 10 " MOLASSES, per bbl., . . 600 "

$\mathrm{N}_{\text {AILS OR SPIKES, per }}$ keg, . . . . . . I Iо“

*OATs, per bush., . . . OIL, per gall. ro lbs, per bbl., • · • • $\cdot$

ONIONS, per bush. 60 lbs., per bbl.,

400 "

OYSTERS, per bush. 90 lbs., per bbl., . . . . . 250 "

${ }^{*} \mathrm{P}$ IANOS, each, . . 2,000" PITCH, per bbl., . . . 300 " PORK, salted, per bbl., . 300 " POTATOES, new, per bush.

70 lbs., per bbl., . . . 175 “ POTATOES, old, per bush.

60 lbs., per bbl., . . . 150 " PORTER, per bbl., . . . 350 "
Rosin, per bbl., . . 300 lbs. “ OIL, per bbl., . 400 " *RYE, per bush., . . . . 60 "

SALT, fine or coarse, per bush. 70 lbs., per bbl., 300 " SAND, per cubic foot, . . 100" *SEWING MACHINES, each 250 " *SHRUBBERY OR TREES,

in full car loads, . . I 2,000 " *SLEIGHS, single, each $\mathrm{r}, 000$

lbs., double, each, . . I, 800 " SYRUP, per gall. $12 \mathrm{x} / 2 \mathrm{lbs}$,

per bbl., . . . . . 600 “ STONE, per cubic foot 180

lbs. unwrought, per cubic

yard 4,200 lbs., wrought do. 5,000 " STONE, per perch of $24 \frac{75}{100}$

cubic feet of broken stone, 3,000 " *STRAW, per car load, . I0,000 “

$\mathrm{T}$ AR, per bbl., . . . 250 “ TELEGRAPH POLES, per cord of I 28 cubic feet, 5,000 " THRESHING MACHINES, single, each, 2000 lbs., double, each, . . . 3,000" TURNIPS, per bush. 60 lbs., per bbl., . . . . 150 "

$V_{\text {INEGAR, per bbl., . . } 400 \text { “ }}$

${ }^{*} W_{\text {heat, per bush., . . } 60 \text { " }}$ WHEELBARROWS, each, 200 " 
WOOD, per cord of 128

cubic feet.

Oak, dry, . . . 3, 300 lbs. "green, . . . . 4,500"

Hickory, dry, . . . . 4,000"
Hickory, green, . . . 5,000 lbs. Hard Pine, dry, . . . 3,300 " "green, . . . 4,200" Soft Pine, dry, . . . 3, 3,000" "green, . . . 4,000 "

The TON, unless otherwise specified, is always understood to be 2,000 pounds.

The maximum weight allowed to be loaded upon any car is 24,000 pounds. (See Rule No. 12 of "Rules and Conditions.")

In calculating lumber upon a car, when the number of feet in board measure is unknown, get the cubic feet, and call every cubic foot Io feet, board measure; if the lumber is of unequal lengths, take that of the longest, unless they are unloaded separately, when each lut can be calculated by itself.

As it is impossible many times to ascertain either the exact weight or measurement of Grain when loaded loose or in bulk, the following calculations are inserted for the guidance of Agents, who will understand that they are only to be used in the absence of more reliable information. Agents will be careful to call the attention of Shippers to Rule No. I I of Rules and Conditions, attached to this Tariff.

A New Market Car 27 feet 7 inches long, and 7 feet 6 inches in width, contains when loaded level one inch in depth, about $13 \frac{855}{1000}$ bush.

An ordinary House Car 27 feet 5 inches long, and 7 feet 5 inches in width, contains when loaded level one inch in depth, about $13 \frac{619}{1000}$ "

\section{NEW MARKET CARS}

26 inches in depth, loaded level with Corn,

contain about 360 bushels, or 20,160 lbs.

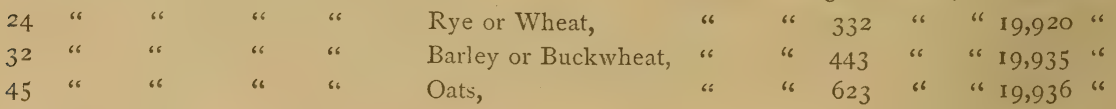

\section{COMMON HOUSE CARS}

26 inches in depth, loaded level with Corn,

$\begin{array}{lllll}25 & 66 & 66 & 66 & 66 \\ 33 & 66 & 66 & 66 & 66 \\ 45 & 66 & 66 & 66 & 66\end{array}$

contain about 354 bushels, or $19,824 \mathrm{lbs}$.

Rye or Wheat, " " " 340 " " 20,400 "

Barley or Buckwheat, " " " " " 449 " 20,205 " "

Oats, " " 612 " " 19,584 “ 


\section{Philaalelphia, Kiflmington \& Paltimore R. R. Co. FREIGHT TARIFF.}

RULES GOVERNING THE WITHIN TARIFF.

All stations on the within table marked thus * are $\mathscr{W} \mathscr{Y}$ stations and have $\mathscr{N O}$ AGENT: Rule No. 17 of "Rules, Regulations and Conditions" must be burne in mind. All others are regular stations having agents.

Freight will be manifested direct between any of the regular stations named within, and the manifests so dated as to reach their. destination upon the day of their date.

The Tariff of Rates does not apply to or from points on any line except those named on following sheets. 


\section{Freight Tariff.}

MILIS.

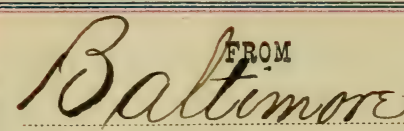

mo

1st Class
Rate
in Cents
per
100 los.

PHILADELPHIA,

GRAY'S FERRY,

*PASCHALL,

*DARBY,

*SHARON HILL,

MOORES,

*RIDLEY PARK,

CHESTER,

LAMOKIN,

THURLOW,

LINWOOD,

CLAYMONT,

*EDGEMOOR,

WILMINGTON,

NEWPORT,

STANTON,

NEWARK,

ELKTON,

NORTH-EAST,

*CHARLESTOWN,

*PRINCIPIO,

PERRY VILLE,

PORT DEPOSIT,

HAVRE-DE-GRACE,

*OAKINGTON,

ABERDEEN,

PERRYMANSVILLE, EDGEWOOD,

2nd Class
Rate
in Cents
per
$100 \mathrm{lbs}$.

3re class

Rate

in Cents

per

100 lbs.

4th Class

Rate

in Cents

per

100 lbs. 


\section{Freight Tariff.}

MILES.

\section{FROM}

TO

Ist Class
Rate
in Cents
per
100 lbs.

2nd Class
Rate
in Cents
per
100 lbs.

$3 r d$ Class
Rate
in Cezts
per
$100 \mathrm{lbs}$.

100 lbs. 4th Class

Rate

in Cents

per

100 lbs.

\section{MAGNOLIA, \\ CHASE'S,}

STEMMER'S RUN,

BALTIMORE,

NEW CASTLE,

*RODNEYS,

KIRKWOOD,

MT. PLEASANT,

MIDDLETOWN,

TOWNSEND,

BLACKBIRD,

GREEN SPRING,

CLAYTON,

SMYRNA,

BRENFORI),

MOORTON,

DOTER,

WYOMING,

WOODSIDE,

CANTERBURY,

FELTON,

HARRINGTON,

FARMINGTON,

GREENWOOD,

BRIDGEVILLE,

SEAFORD,

LAUREI,

DELMAR,

ì

E

1210

12

10

22

2522

2320

25

$2 y$

24

23

24

30

30

30

30

32

32

32

32

35

35

35

34

40

40

42

f

22

22

22

$2\}$

23

23

23

28

38

क 0

32

8

8

8

6

14

$1 /$

$y$

6

0

15

12

15

12

$15^{-}$

12

15

12

15

12

22

15

12

15

12

22

19

14

y

22

22

$1 y$

$y$

18

18

18

14

13

14

15

15

15

18

20

$1 v$

6

20

16

2016

22

23

$1 y$

23

32

34
$25-20$ 
36

Freight Tariff.

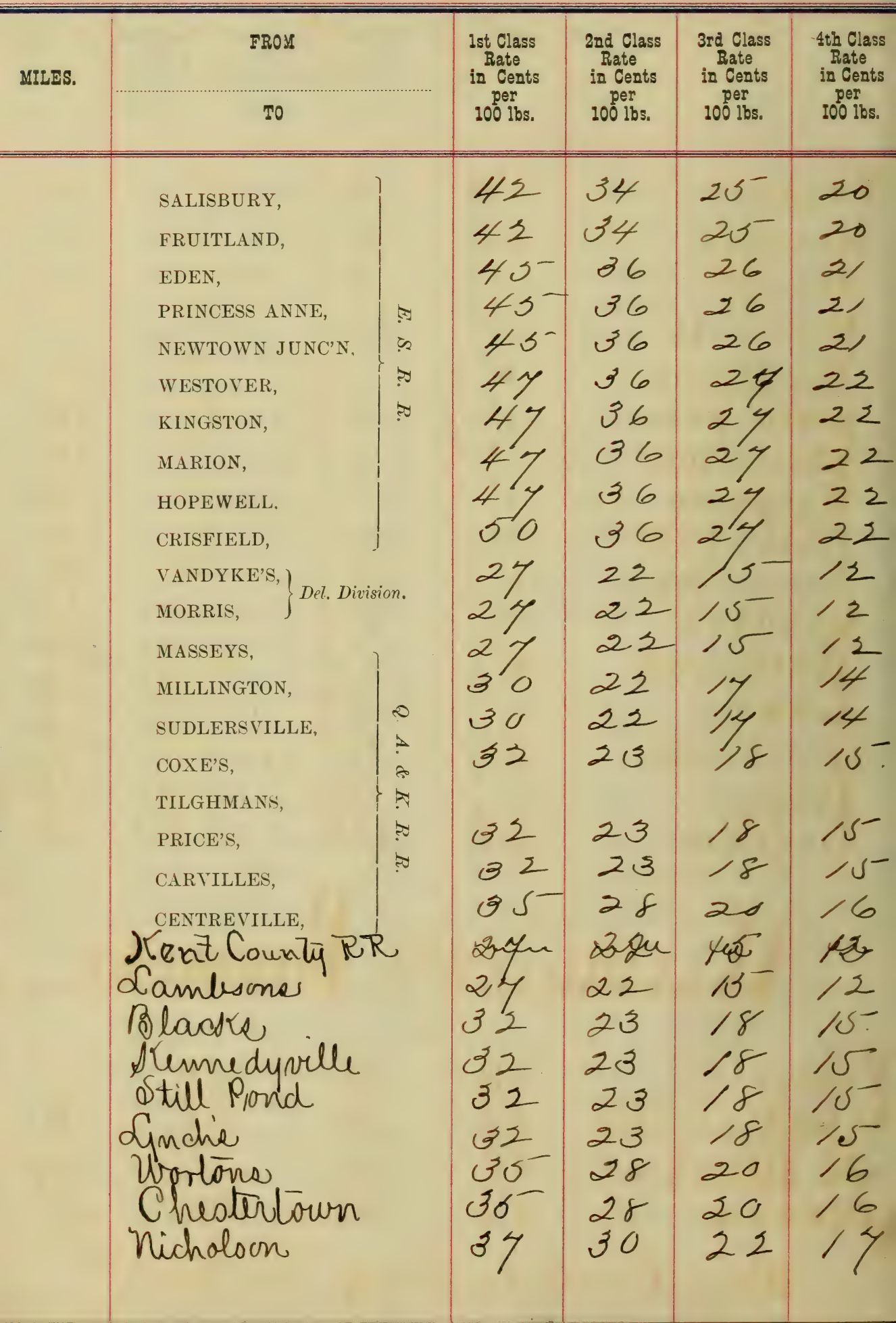


$.9 .4,13$ is a dill,
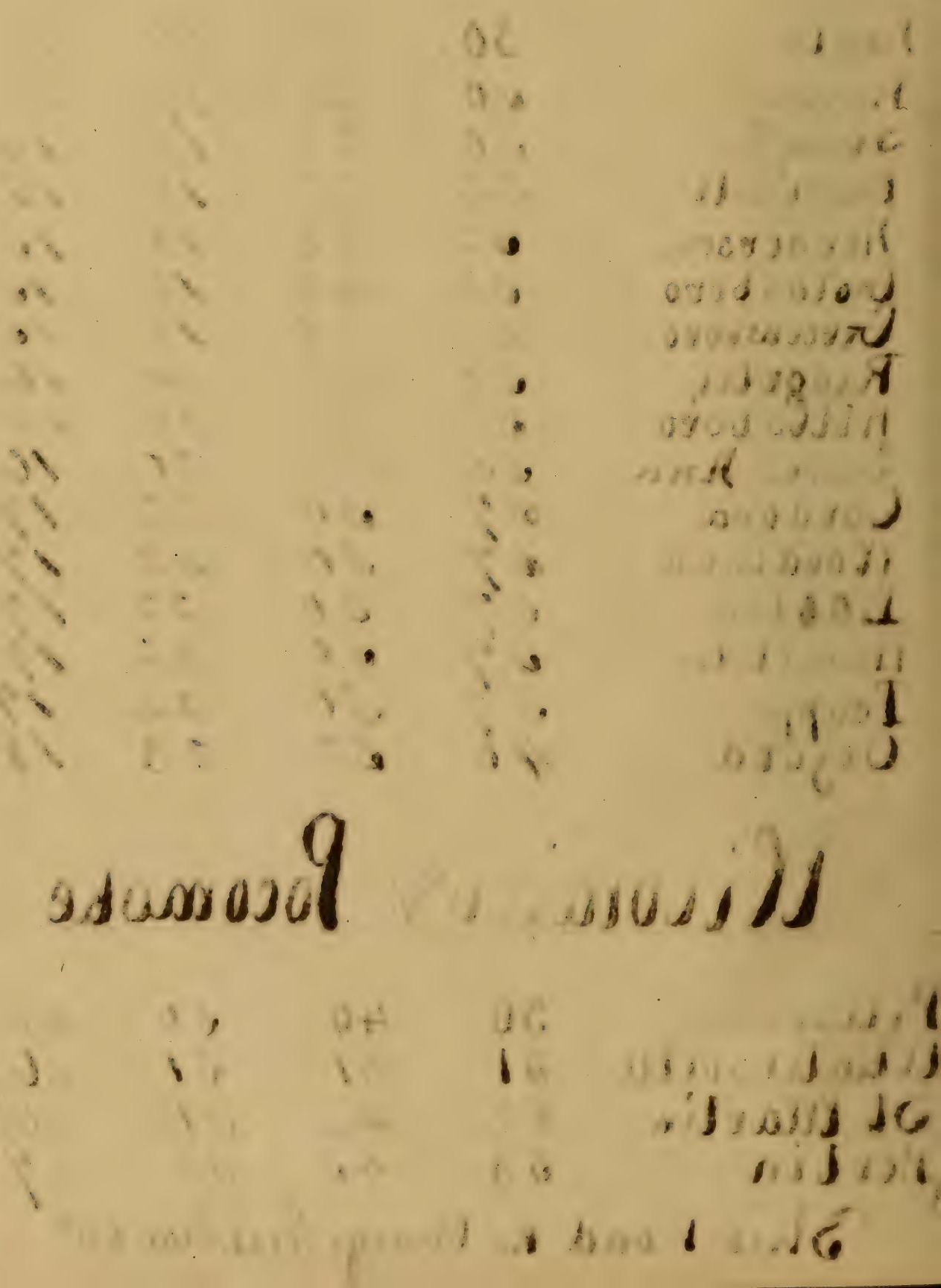


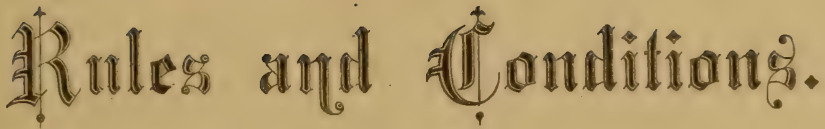

1. The business of the Freight Department of the Company is to transport such articles as can be properly carried in freight cars. Money, Jewelry, Gold or Silver Ware, important papers or other similar valuables will not be received or transported except by special agreement. No Station Agent or Conductor is authorized to make such agreements.

2. Gunpowder, Nitro Glycerine, Fire Works and other explosive articles will only be taken by special agreement, and if secreted among other freight will be forfeited and the shipper held responsible in case of damage.

3. Agents are instructed to receive no freight for transportation UNLESS IN GOOD SHIPPING ORDER, properly packed and plainly marked with consignee's name and destination in such manner that the marks will not be effaced : with ordinary handling. Goods in paper bundles (or marked with paper labels) will not be considered as properly packed, and this Company will not be responsible for their loss or damage. Small articles of metal, as plow points, washers, small bolts and nuts, will not be received unless boxed or otherwise well secured. DEMIJOHNS and CARBOYS will not be taken unless securely boxed and the nature of their contents made known to the Compdny.

4. -All packages will be subject to a charge for cooperage, if necessary.

5. When an invoice covers a variety of articles, as a lot of household furniture, \&c., each separate piece or package must be properly marked, or no allowance for deficiency will be made. Carriage Cushions, Rugs and Harness will not be received or shipped as a part of the carriage, but must be properly baled, marked, invoiced and charged for, as if sent by themselves. 
6. The Company will not be responsible for injury done to cattle or horses in consequence of their being unruly, wild or vicious, or for injury to calves, hogs, or other stock from suffocation, exhaustion, heat or cold on the passage. Calves will be received for shipment only on such days as the Company may elect.

7. Freight must be prepaid in all the following cases : Ist. When the Company's agents do not consider the articles worth the charge for freight, if sold at a forced sale. 2nd. When the articles are perishable, as Fresh Fish, Poultry, Green Fruit, Green Vegetables, \&c. 3rd. Live Stock. 4th. All freight sent by passenger trains. 5th. All freights consigned to and delivered at points on the line of the road where there are no authorized agents of the Company.

8. The Company will not be responsible for any damage occasioned by delays from storms, accidents or other providential causes, nor for decay of perishable articles, or injury by frost and heat to such articles as are affected thereby. Neither will they guarantee any special dispatch in the transportation of any article; nor will they hold themselves liable for damages by fire or as common carriers, for any article after its arrival at its place of destination and unloaded in the Company's warehouses or stations.

9. This Company will not be responsible for the leakage of Liquids, breakage of Glassware, Looking Glasses, Furniture, Eggs, Marble Slabs, or for damages to the hidden contents of packages caused by improper packing, or for the lnss of Nuts, or Shot, forwarded in bags, nor for any deficiency in Dry Goods, Boots and Shoes, Hats, Caps and Straw Goods, unless the packages are properly strapped and secured when received.

Io. The measurement of all Timber and Lumber, and weight of other freight in bulk, must be furnished by the consignor; and if it shall appear to the Company's agents to be understated, the Company reserves the right to cause the same to be re-measured or re-weighed by a competent and disinterested person, and to detain the freight either at the place of shipment or at its destination until so weighed or measured, and freight paid on the excess (if any be found). In which case also the expense of such service will be charged. The Company will not be responsible for shortage of freight when loaded in bulk by the shipper, or unloaded by consignees. Cars will not be loaded with freight in bulk unless the quantity is at least half a car load. 
II. The maximum weight allowed to be loaded on a car is 24,000 pounds for an eight-wheel car. When any excess in weight over this amount is known to be shipped upon a car, such excess will be charged for, additional to the car load price, at such figures as the Company may decide.

12. No single article going alone, however small, will be transported any distance for less than 25 cents, or rated at less than 50 pounds. When the same consignee however has various articles of different classifications, which when properly classified and freight charged thereon do not amount to 25 cents each, but amount to, or more than, the sum in the aggregate, they should be charged at the amounts according to the classification.

13. Freight will be taken on passenger trains only at the Company's convenience. If taken, must be prepaid at double First Class Rates, unless by special agreement.

I 4. Articles that are bulky, long, or inconvenient to handle, will be charged extra at discretion.

15. All packages whose contents are unknown will be charged for at First Class Rates.

I6. Merchandise loaded by the consignors from points on the line of the road where there are no Agents, will be accounted for as it tallies out at the point of delivery. Merchandise loaded at such points by the Company's employès will be accounted for as it tallies into the cars when loaded. Merchandise delivered at such points will be accounted for as it tallies out of the cars, and all articles in any case at such stations will be wholly at the risk of the owner.

I7. Freight destined for stations where there are no Agents, will be manifested prepaid at the rate of the next regular station beyond and the manifest sent to the Agent of that station. Freights taken from stations where there are no Agents, will be manifested by the Agent of the first regular station south of the way station.

18. All rates of freight in bulk are given with the understanding that the loading and unloading are to be done without expense to the Rail Road Company, and without detaining a car more than twenty-four hours either to load or unload. The Rail Road Company reserves the right however, if cars are greatly needed, to 
unload Coal or Lime immediately upon its arrival at its destination, or freight of other kinds at any time after twenty-four hours, and to charge the consignee with the cost of doing so. If obliged so to unload, the Company will not be responsible for loss or damage resulting. Cars delayed more than twenty-four hours will be subject to an extra charge for each day's detention of fifty cents on each fourwheeled, or one dollar on each eight-wheeled lime or coal car, or three dollars for each eight-wheeled car of other descriptions.

19. The Company will not be responsible for any merchandise unless the same be receipted for by a duly authorized Agent. When receipts are required, duplicates ready for signing must be furnished by the consignor, and if the articles are designed after transportation upon this Rail Road to be forwarded upon some other line to their final destination, such receipt must specify the same and the articles be marked accordingly. This Company will not be responsible for such articles after they are delivered as designated in said receipt, or to a carman or other carrier whose business is to transport goods between different Rail Road depots and the depots of other transportation lines.

20. No expenses will be advanced except for transportation or loading, unloading, cooperage \&c., and then not to an amount exceeding the value of the article at a forced sale, and in no case upon perishable articles, unless when received from some other transportation line and such line guarantees the payment of such charges.

21. Special tariffs will be issued from time to time for Fruits, Marketing, Coal and Lime. In the absence of special tariffs for these articles, this tariff must be used. It will be understood that any special season tariff will only be applicable for the particular season for which it is issued.

22. No special rates or deviations from the foregoing can be made except by the General Freight Agent.

23. All claims for losses, overcharges or damages must be reported to the General Freight Agent for adjustment.

24. All bulk freight received from or forwarded to the DELAWARE DIVISION, will be subject to scale weight taken at the Middletown Scales, and all articles will be carried at their actual weight, when the same can be ascertained. 
25. The Ton, unless otherwise specified, to be 2,000 pounds.

26. The Company reserve the right to abrogate or change any of their rates, classifications or conditions at any time.

27. Agents must make themselves familiar with all the provisions of this Tariff, and for any loss or damage which may be imposed upon the Company through their negligence or violation of any of the conditions or rules herein contained, they will be held to a strict personal responsibility.

This Tariff supersedes all others of previous date, and all rates conflicting with the foregoing, whether special or otherwise, are canceled upon the issue of this tariff.

JOHN S. WILSON,

General Freight Agent. 




